\title{
Large hemispheric difference in nucleation mode aerosol concentrations in the lowermost stratosphere at mid- and high latitudes
}

\author{
Christina J. Williamson ${ }^{1,2}$, Agnieszka Kupc ${ }^{2,3}$, Andrew Rollins ${ }^{2}$, Jan Kazil ${ }^{1,2}$, Karl D. Froyd ${ }^{1,2}$, Eric A. Ray ${ }^{1,2}$, \\ Daniel M. Murphy ${ }^{2}$, Gregory P. Schill ${ }^{1,2}$, Jeff Peischl ${ }^{1,2}$, Chelsea Thompson ${ }^{1,2}$, Ilann Bourgeois ${ }^{1,2}$, \\ Thomas B. Ryerson ${ }^{2, a}$, Glenn S. Diskin ${ }^{4}$, Joshua P. DiGangi ${ }^{4}$, Donald R. Blake ${ }^{5}$, Thao Paul V. Bui ${ }^{6}$, \\ Maximilian Dollner ${ }^{3}$, Bernadett Weinzierl ${ }^{3}$, and Charles A. Brock ${ }^{2}$ \\ ${ }^{1}$ Cooperative Institute for Research in Environmental Sciences, University of Colorado, Boulder, CO 80309, USA \\ ${ }^{2}$ Chemical Sciences Laboratory, National Oceanic and Atmospheric Administration, Boulder, CO 80305, USA \\ ${ }^{3}$ Faculty of Physics, Aerosol Physics and Environmental Physics, University of Vienna, 1090 Vienna, Austria \\ ${ }^{4}$ NASA Langley Research Center, Hampton, VA 23681, USA \\ ${ }^{5}$ Department of Chemistry, University of California Irvine, Irvine, CA 92697, USA \\ ${ }^{6}$ Earth Science Division, NASA Ames Research Center, Moffett Field, California, USA \\ anow at: Scientific Aviation, Boulder, CO 80301, USA
}

Correspondence: Christina J. Williamson (christina.williamson@noaa.gov)

Received: 11 January 2021 - Discussion started: 22 January 2021

Revised: 6 April 2021 - Accepted: 11 April 2021 - Published: 15 June 2021

\begin{abstract}
The details of aerosol processes and size distributions in the stratosphere are important for both heterogeneous chemistry and aerosol-radiation interactions. Using in situ, global-scale measurements of the size distribution of particles with diameters $>3 \mathrm{~nm}$ from the NASA Atmospheric Tomography Mission (ATom), we identify a mode of aerosol smaller than $12 \mathrm{~nm}$ in the lowermost stratosphere (LMS) at mid- and high latitudes. This mode is substantial only in the Northern Hemisphere (NH) and was observed in all four seasons. We also observe elevated $\mathrm{SO}_{2}$, an important precursor for new particle formation (NPF) and growth, in the NH LMS. We use box modelling and thermodynamic calculations to show that NPF can occur in the LMS conditions observed on ATom. Aircraft emissions are shown as likely sources of this $\mathrm{SO}_{2}$, as well as a potential source of nucleation mode particles directly emitted by or formed in the plume of the engines. These nucleation mode particles have the potential to grow to larger sizes and to coagulate with larger aerosol, affecting heterogeneous chemistry and aerosol-radiation interactions. Understanding all sources and characteristics of stratospheric aerosols is important in the context of anthropogenic climate change as well as propos-
\end{abstract}

als for climate intervention via stratospheric sulfur injection. This analysis not only adds to the, currently sparse, observations of the global impact of aviation, but also introduces another aspect of climate influence, namely a size distribution shift of the background aerosol distribution in the LMS.

\section{Introduction}

Aerosols in the stratosphere have both radiative and chemical effects: (i) scattering or absorbing light which cools or warms the Earth and (ii) providing surfaces for heterogeneous chemical reactions. Aerosol lifetimes are much longer in the stratosphere than in the troposphere, increasing their influence (Crutzen, 2006). Recently, much attention has been given to climate intervention by direct stratospheric aerosol injection, or by injection of gas-phase species that can form particles in the stratosphere (Shepherd, 2012; Council, 2015; Keith et al., 2014; MacMartin and Kravitz, 2019, National Academies of Sciences, Engineering, and Medicine, 2021). For these reasons, it is imperative that the background state, sources of, and trends in stratospheric aerosols are well un- 
derstood and can be accurately reproduced and predicted by global climate models. Aerosols in the lowermost stratosphere (LMS) are highly variable, even in the absence of major volcanic eruptions (Solomon et al., 2011), and models currently struggle to reproduce observed aerosol size distributions in this region of the atmosphere (Murphy et al., 2020).

Volcanic eruptions are a major source of stratospheric aerosols and precursor gases (Solomon et al., 2011; Vernier et al., 2011; Kremser et al., 2016). Aerosols and precursor gases can also enter the stratosphere from the tropical tropopause layer (TTL) either quasi-isentropically into the extratropical LMS or cross-isentropically into the tropical stratosphere. The latter can occur both via slow radiative heating or by overshooting convection (Kremser et al., 2016). The stratospheric aerosol background (in volcanically quiescent periods) is highly variable, and it is unclear how much this is affected by anthropogenic influence (Solomon et al., 2011). Increases in the amount of aerosol in the stratosphere have been observed recently, but whether this is due to anthropogenic emissions (Hofmann et al., 2009; Randel et al., 2010) or minor volcanic eruptions (Vernier et al., 2011; Neely III et al., 2013; Brühl et al., 2015; Mills et al., 2016) remains unclear. Recent studies have shown pollution from the Asian summer monsoon affecting stratospheric aerosol (Yu et al., 2017; Lelieveld et al., 2018). These studies have focused on gas-phase species and particles without details of the nucleation mode. Pyro-convection is another possible source of particles in the LMS (Fromm and Servranckx, 2003; Damoah et al., 2006; Ditas et al., 2018; Yu et al., 2019), as is dust (Murphy et al., 2014). Two distinct aerosol accumulation modes (particles with diameters between 60 and $1000 \mathrm{~nm}$ ) have recently been identified in the LMS: one originating at higher altitudes in the stratosphere and one entrained from the upper troposphere (UT) (Murphy et al., 2020).

Under a range of conditions, aerosols can form in situ from the gas phase, in a process known as new particle formation. New particle formation (NPF) has been well documented in a variety of locations in the planetary boundary layer and free troposphere (Clarke et al., 1998, 2013; Kulmala et al., 2013; Williamson et al., 2019). NPF in the TTL has been observed (Brock et al., 1995), as has wintertime NPF in the polar middle stratosphere (Campbell and Deshler, 2014; Wilson et al., 1992). Aircraft and, more recently, rocket emissions are possible sources of nucleation mode particles or precursor gases in the stratosphere (Lee et al., 2010; Schröder et al., 2000; Brock et al., 2000).

Atmospheric NPF is known to often involve sulfuric acid $\left(\mathrm{H}_{2} \mathrm{SO}_{4}\right)$ and water (Kuang et al., 2008; Kulmala et al., 2013), highly oxidized organic molecules (Bianchi et al., 2019; Gordon et al., 2017; Riccobono et al., 2014; Stolzenburg et al., 2018), and ions (Duplissy et al., 2016; Kirkby et al., 2011, 2016), where they are present. Ammonia and amines have been shown to contribute to NPF in the plane- tary boundary layer and in the free troposphere (Ball et al., 1999; Kürten et al., 2016; Bianchi et al., 2016; Smith et al., 2010; Almeida et al., 2013).

Most studies of atmospheric NPF are related to occurrence in the planetary boundary layer (PBL) (Kerminen et al., 2018). While it is obvious that the LMS is a very different environment from the PBL, it is worth drawing attention to the ways in which the unique environment of the LMS could be important for NPF. Firstly, the colder temperature of the LMS may influence NPF and growth in complex ways (Paasonen et al., 2013; Dada et al., 2017). Low temperatures found in the UT and LMS reduce the vapour pressure of $\mathrm{H}_{2} \mathrm{SO}_{4}$, increasing rates of binary $\left(\mathrm{H}_{2} \mathrm{SO}_{4}-\mathrm{H}_{2} \mathrm{O}\right)$ nucleation (Easter and Peters, 1994). Low temperatures also decrease volatility, thereby increasing the semi-volatile organic species that can contribute to new particle formation and growth (Trostl et al., 2016; Stolzenburg et al., 2018; Simon et al., 2020). Secondly, the drier environment of the LMS means that water is less available for NPF and growth than is usually the case in the PBL. Thirdly, total concentrations of aerosol and the related sinks for condensable vapours, clusters, and nucleation mode particles are generally higher in the PBL, so PBL NPF is mostly observed where concentrations of precursor vapours are high or under specific local conditions where condensation sinks are lower (Kerminen et al., 2018). In contrast, it may be possible for lower concentrations of condensable vapours to cause NPF in the LMS because of these low sinks. These low sinks in the LMS mean that we are essentially observing processes like NPF and growth in the LMS in slow motion when compared to the PBL. Low sinks and low concentrations of more standard precursor gases mean that unconventional nucleation mechanisms may become important in the LMS. It has been postulated that gas-phase mercury could cause NPF under the right conditions, and one such possible event has been observed in the marine boundary layer near Antarctica (Humphries et al., 2015). Mercurycontaining aerosols have been observed in the LMS (Murphy et al., 2006). Iodine oxidation has been linked to atmospheric NPF in coastal regions (McFiggans et al., 2010; O'Dowd et al., 1999, 2002; Sipila et al., 2016) and over the arctic ice pack (Baccarini et al., 2020). Iodine and bromine have both been observed in the UT (Volkamer et al., 2015; Dix et al., 2013) and stratosphere (Koenig et al., 2020). Lastly, ozone levels are, apart from for some specific highly polluted areas in the PBL, higher in the LMS. This may well lead to different oxidation mechanisms than we typically consider in the troposphere.

It is imperative that we understand factors that regulate aerosol number in the lower stratosphere because this affects how condensed material in the stratosphere is apportioned to size, thus influencing heterogeneous chemistry, light scattering, absorption, and sedimentation (Wilson et al., 2008). Nucleation mode particles (3-12 nm in diameter) have the potential to influence all of these properties in the LMS. Climate intervention schemes that propose the injection of 
aerosols, or their precursor gases into the stratosphere, could be affected by the presence of nucleation mode aerosol, which can remove gases and particles through condensation and coagulation.

Here we examine in situ observations of nucleation mode particles, as well as relevant gas-phase tracers and condensable species in the lowermost stratosphere in both hemispheres, to understand the prevalence, potential causes, and importance of NPF in the LMS. Hemispheric differences in observed aerosol and cloud properties are a tool for understanding anthropogenic effects, since we can contrast the more anthropogenically influenced Northern Hemisphere (NH) with the less anthropogenically influenced Southern Hemisphere (SH). This technique has been previously used to constrain aerosol radiative forcing using observations of cloud droplet number (McCoy et al., 2020). We use box modelling, back trajectories, thermodynamic calculations, and emissions estimates to understand how NPF can occur in the LMS, factors influencing the amount of NPF, and other potential sources of nucleation mode aerosol in this region.

\section{Methods}

We recently conducted global-scale in situ aerosol observations on the NASA Atmospheric Tomography Mission (ATom) (Wofsy et al., 2018). This mission consisted of four sets of near pole-to-pole flights on the NASA DC-8 over the remote Pacific and Atlantic oceans. Flight paths continuously scanned from $\sim 0.2$ to $\sim 12 \mathrm{~km}$ altitude to measure the vertical structure of the atmosphere, and these paths were covered once in each of the four seasons to capture seasonal variability.

We measured aerosol size distributions from $3 \mathrm{~nm}$ to $4.5 \mu \mathrm{m}$ using instruments inside the cabin of the DC- 8 using nucleation mode aerosol size spectrometers (NMASS), modified ultra-high-sensitivity aerosol spectrometers (UHSASs), and a laser aerosol spectrometer (LAS, TSI Inc., St. Paul, MN, USA) (Williamson et al., 2018; Kupc et al., 2018; Brock et al., 2019). A second-generation Cloud, Aerosol and Precipitation Spectrometer (CAPS; Droplet Measurement Technologies), mounted under the aircraft's wing, extended the measured size range of aerosol and cloud size distributions covering the range between approximately 0.5 and $930 \mu \mathrm{m}$. (Spanu et al., 2020). Size-resolved single-particle composition measurements were made using the particle analysis by laser mass spectrometry instrument installed inside the cabin (Froyd et al., 2019). $\mathrm{SO}_{2}$ observations with a detection limit of 1 part per trillion by volume (pptv; nmol mol${ }^{-1}$ ) were made on the fourth set of flights (May 2018) using laser-induced fluorescence techniques (Rollins et al., 2017). Stratospheric air is identified using in situ measurements of ozone and relative humidity. Ozone was measured using nitric-oxide-induced chemiluminescence (Bourgeois et al., 2020), water vapour was measured by the diode laser hy- grometer (Diskin and Digangi, 2019; Diskin et al., 2002), and global positioning and meteorological data were measured by the meteorological measurement system (Scott et al., 1990; Gaines et al., 1992; Chan et al., 1989). Trace gases were sampled using the whole-air-sampler (WAS) system (Colman et al., 2001) and then analysed in the laboratory using multi-column gas chromatography utilizing flame ionization detectors (FIDs), electron capture detectors, and a mass selective detector (MSD). The $\mathrm{CH}_{3} \mathrm{Cl}$ is detected on the MSD and one of the FIDs while ethane is detected on another FID.

Measured aerosol size distributions are used to calculate condensation and coagulation rates. The coagulation kernel between two particles as a function of their diameters is calculated using the Fuchs expression for the coagulation rate coefficient (Seinfeld and Pandis, 2006) at ambient pressure and temperature. We assume each particle to have the density of water $\left(1000 \mathrm{~kg} \mathrm{~m}^{-3}\right)$. The condensation is calculated in the same way, substituting a molecule of sulfuric acid for one of the particles. The diameter of a sulfuric acid molecule is calculated from bulk properties following the method from Lovejoy et al. (2004), neglecting temperature effects on the probability distribution function of monomers, dimers, and trimers. We sum the coagulation and condensation rate from all particles in the size distribution at each measurement time. Condensation and coagulation rates will be used in this analysis to relate our observations to theory and models and to estimate particle lifetimes.

While ATom flights were not designed for stratospheric sampling, measurements were made of the LMS at mid-high latitudes in both hemispheres on all deployments. Measurements were limited to altitudes below $13 \mathrm{~km}$, so stratospheric air sampled was associated with a low tropopause and sometimes tropopause folds. For this reason, we choose to define the stratosphere here as ozone $>250$ parts per billion by volume (ppbv), altitude $>8 \mathrm{~km}$ so as to be definitively above the tropopause, and relative humidity $<10 \%$ with respect to supersaturated water. For interhemispheric comparisons we mainly choose to examine stratospheric air with ozone $<400$ ppbv. Most of the Southern Hemisphere (SH) flights did not reach ozone $>400$ ppbv, whereas higher ozone mixing ratios were sampled in the $\mathrm{NH}$. Therefore, the ozone range from $250-400 \mathrm{ppbv}$ was chosen to ensure consistent comparison between hemispheres. This stratospheric definition is consistent with that used by Murphy et al. (2020), which we will reference in this analysis. Figure 1 shows the flight paths of the ATom deployments, highlighting where the LMS was sampled.

Size distributions can be used to identify particles that have recently formed via NPF. Stable particles form at around $1.7 \mathrm{~nm}$ diameter from the growth of molecular clusters. Lifetimes of these newly formed particles are relatively short, on the order of a few days (Sect. S1), so their presence indicates recent NPF. The size distribution at the smallest sizes is measured by a battery of 5 (for ATom 1) or 10 (for ATom 2-4) condensation particle counters within the 


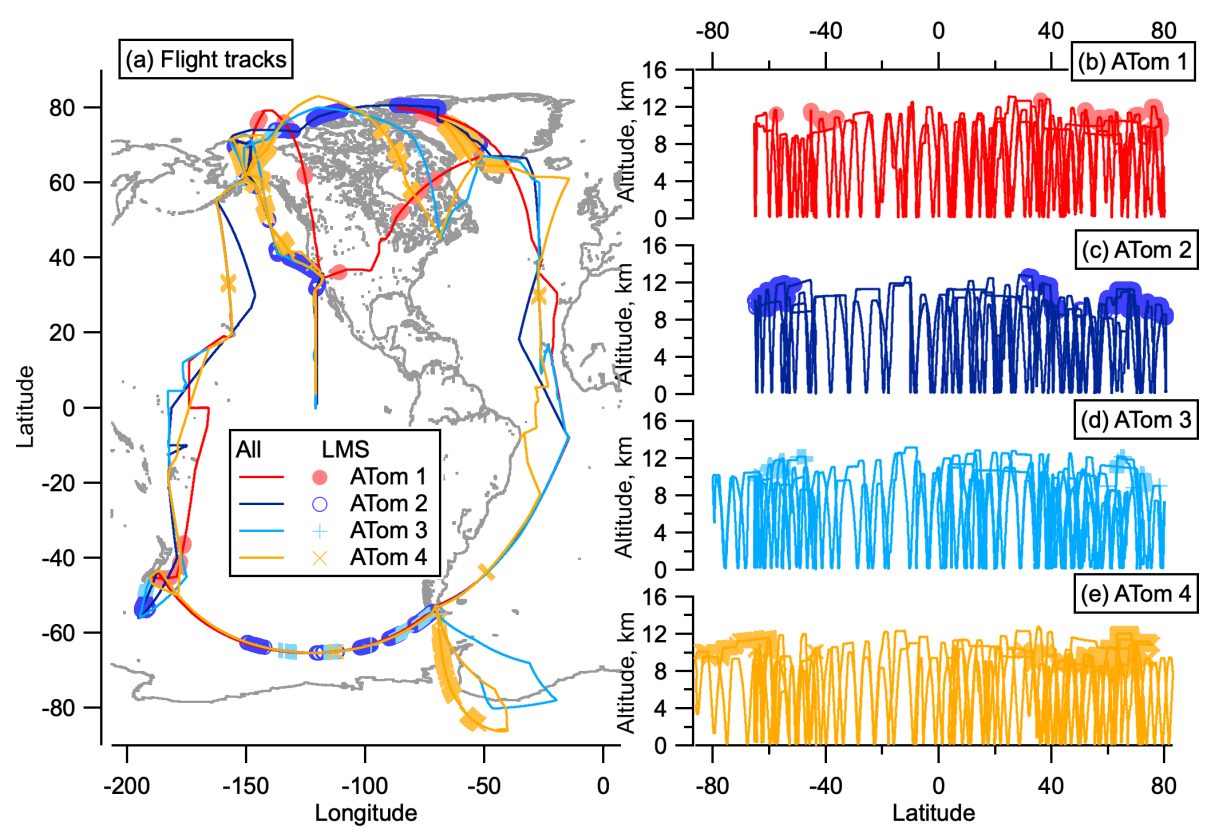

Figure 1. ATom flight locations. Flight tracks from ATom in all four seasons as a function of latitude and longitude (a) and altitude and latitude (b-e). Sampling in the LMS $\left(\mathrm{O}_{3}>250 \mathrm{ppbv}\right.$ and relative humidity over water $\left.\left(\mathrm{RH}_{\mathrm{W}}\right)<10 \%\right)$ is highlighted in light-coloured symbols. The world map was made with Natural Earth free vector and raster map data, http://www.naturalearthdata.com (last access: 10 December 2015).

NMASS instruments that each measure the total number concentration of particles larger than a specified size. These concentrations are differenced to give the total number of particles in 5-10 size bins from between 3 and $60 \mathrm{~nm}$ (Williamson et al., 2018). Recent NPF is diagnosed when number concentrations in the smallest measured size bin are larger than those in the next-smallest size bin by 3 times more than can be expected by uncertainty due to flow variation and counting statistics (Williamson et al., 2019). In this analysis we divide the aerosol size distribution into four modes: nucleation mode from 3-12 nm, Aitken mode from $12-60 \mathrm{~nm}$, accumulation mode from $60-1000 \mathrm{~nm}$, and coarse mode above $1000 \mathrm{~nm}$. We note that the $12 \mathrm{~nm}$ cut-off between nucleation and Aitken modes is defined at a smaller diameter than is often used for aerosol studies in the lower troposphere and make this choice to allow for more direct comparison with previous datasets over the remote Pacific and Atlantic oceans (Clarke and Kapustin, 2002, 2010; Clarke et al., 1998, 1999, 2013) and for consistency with the ATom data archive (Wofsy et al., 2018) and other published works analysing ATom size distributions (Brock et al., 2019; Kupc et al., 2020; Williamson et al., 2019).

Using a simple thermodynamic analysis, we assess whether LMS conditions prohibit or allow NPF via nucleation of the negative ion binary $\mathrm{H}_{2} \mathrm{SO}_{4}-\mathrm{H}_{2} \mathrm{O}$ system. Bulk solutions have a characteristic $\mathrm{H}_{2} \mathrm{SO}_{4}$ saturation vapour pressure (SVP), which describes the thermodynamic driving force for condensation or evaporation of $\mathrm{H}_{2} \mathrm{SO}_{4}$. Similarly, each molecular cluster in the binary $\mathrm{H}_{2} \mathrm{SO}_{4} / \mathrm{H}_{2} \mathrm{O}$ system has a characteristic SVP value (Froyd and Lovejoy, 2012). SVP is a strong function of temperature and also depends on relative humidity $(\mathrm{RH}) . \mathrm{SVP}_{\max }$ is the maximum SVP value that growing clusters experience for a given RH. Using cluster thermodynamics that form the basis for the Model of Aerosols and Ions in the Atmosphere (MAIA) model (Lovejoy et al., 2004; Kazil and Lovejoy, 2007; Kazil et al., 2007), we define the barrier to nucleation for the negative ion system as the ratio of $\mathrm{SVP}_{\max }$ to the typical daytime maximum $\mathrm{H}_{2} \mathrm{SO}_{4}$ concentration. When the ratio of $\mathrm{SVP}_{\max }$ to the partial pressure of $\mathrm{H}_{2} \mathrm{SO}_{4}\left(p\left(\mathrm{H}_{2} \mathrm{SO}_{4}\right)\right)$ is $>1$, it is more energetically favourable for a cluster to evaporate $\mathrm{H}_{2} \mathrm{SO}_{4}$ than for molecules to condense onto that cluster. At ratios $>10$, NPF is highly improbable. When $\mathrm{SVP}_{\max } / p\left(\mathrm{H}_{2} \mathrm{SO}_{4}\right)<1$, cluster growth is more energetically favourable than evaporation, and nucleation proceeds with no thermodynamic barrier.

To more quantitatively assess the effects of thermodynamics on NPF in the LMS, box modelling is performed using MAIA. MAIA describes the oxidation of $\mathrm{SO}_{2}$ to gaseous $\mathrm{H}_{2} \mathrm{SO}_{4}$, the nucleation of neutral and negative $\mathrm{H}_{2} \mathrm{SO}_{4}$ $\mathrm{H}_{2} \mathrm{O}$ clusters, aerosol growth by sulfuric acid condensation / evaporation, and particle coagulation. The production rate of $\mathrm{H}_{2} \mathrm{SO}_{4}$ is calculated assuming that the reaction of $\mathrm{SO}_{2}+\mathrm{OH}$ is the rate-limiting step of the oxidation of $\mathrm{SO}_{2}$ to form $\mathrm{H}_{2} \mathrm{SO}_{4}$ (Lovejoy et al., 1996). Nucleation is described with laboratory thermochemical data for $\mathrm{H}_{2} \mathrm{SO}_{4}$ and $\mathrm{H}_{2} \mathrm{O}$ uptake and loss by small neutral and negative clusters (Curtius et al., 2001; Lovejoy and Curtius, 2001; Froyd and Lovejoy, 2003; Hanson and Lovejoy, 2006). The thermochemical 

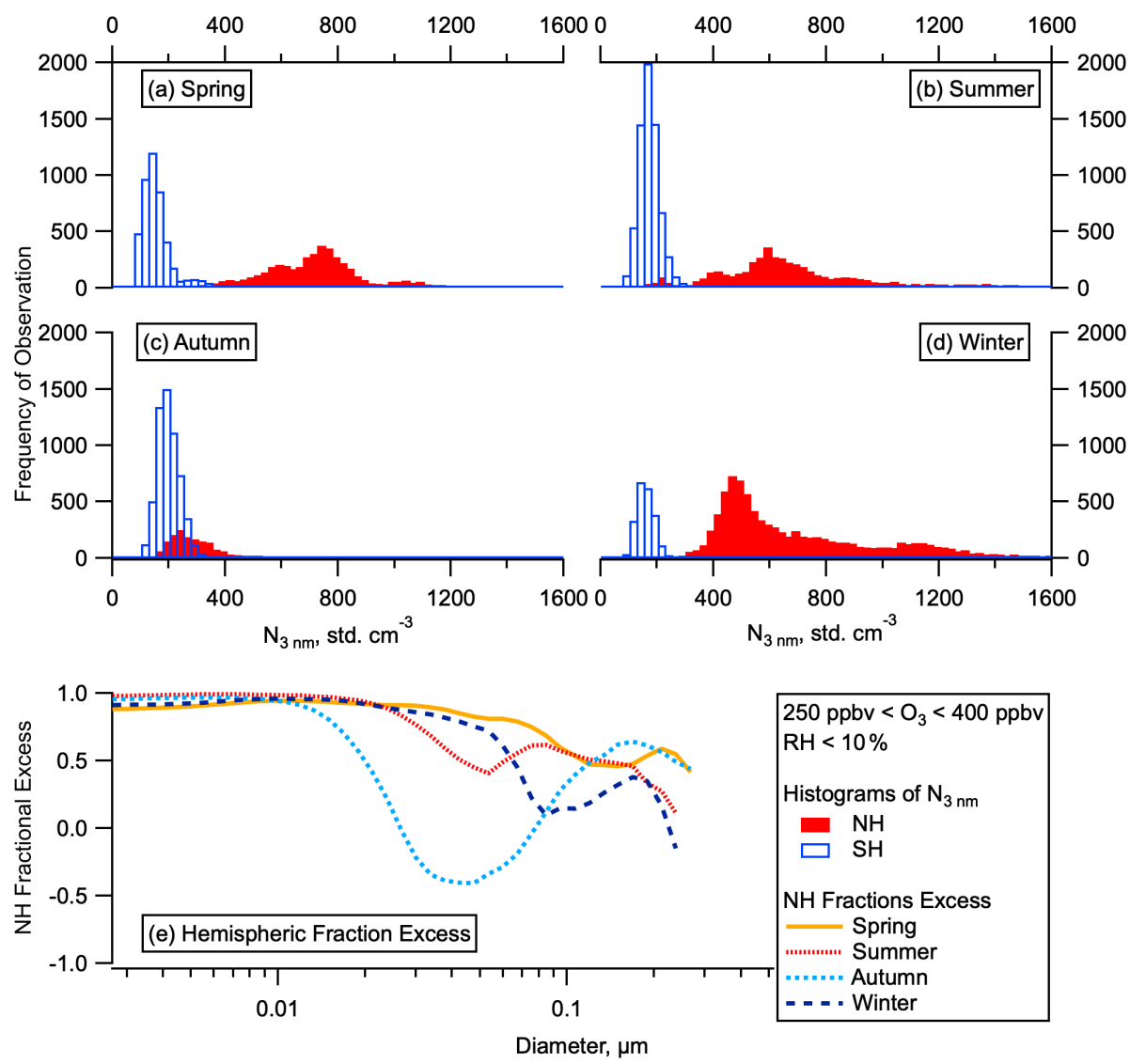

Figure 2. Hemispheric differences in particle number and concentrations. Histograms of the total number of aerosol between 3 and $4500 \mathrm{~nm}$ in the LMS (ozone 250-400 ppbv, altitude $>8 \mathrm{~km}$ ) for the $\mathrm{SH}$ and $\mathrm{NH}$ for all for ATom deployments (a-d) by season. Fractional excess of mean particle number in the $\mathrm{NH}$ compared to the $\mathrm{SH}\left(\left(N_{\mathrm{NH}}-N_{\mathrm{SH}}\right) / N_{\mathrm{NH}}\right)$ in each season as a function of particle diameter (e).

data for uptake and loss of $\mathrm{H}_{2} \mathrm{SO}_{4}$ and $\mathrm{H}_{2} \mathrm{O}$ by large sulfuric acid aerosol ( $\gg 5$ sulfuric acid molecules) are based on the liquid drop model and $\mathrm{H}_{2} \mathrm{SO}_{4}$ and $\mathrm{H}_{2} \mathrm{O}$ vapour pressures over bulk solutions. These were calculated with a computer code (provided by S. L. Clegg, personal communication, 2007) which adopts experimental data from Giauque et al. (1960) and Clegg et al. (1994). The thermochemical data for intermediate-sized particles are a smooth interpolation of the data for small and large aerosol particles. The model uses 20 linear bins in which $\mathrm{H}_{2} \mathrm{SO}_{4}$ content increases by 1 molecule per bin and 50 geometric bins in which $\mathrm{H}_{2} \mathrm{SO}_{4}$ content increases by a factor of 1.45 per bin, covering a dry $(312.15 \mathrm{~K}, 10 \% \mathrm{RH})$ particle diameter range of $\sim 0.5-$ $800 \mathrm{~nm}$.

MAIA operates along trajectories with changing pressure, temperature, and relative humidity (Kazil and Lovejoy, 2007) in the temperature range $180-320 \mathrm{~K}$ and the relative humidity range $1 \%-101 \%$, which includes upper troposphere conditions. MAIA parameterizes the $\mathrm{OH}$ diurnal cycle as a half sine centred around noon with a prescribed noon $\mathrm{OH}$ concentration, while setting the nighttime $\mathrm{OH}$ concentration to 0 . The length of the daytime period is calcu- lated from the day of year and location. Atmospheric ionization rates due to galactic cosmic rays are calculated as a function of latitude, altitude, and solar cycle phase by a model of energetic particle transport in the Earth's atmosphere (O'Brien, 2005). The transformation between geographic and geomagnetic coordinates is calculated with GEOPACK (http://geo.phys.spbu.ru/ tsyganenko/modeling. html, last access: 7 August 2018) and the International Geomagnetic Reference Field 12 coefficients (https://www.ngdc. noaa.gov/IAGA/vmod/igrf.html, last access: 7 August 2018).

Aerosol nucleation rates calculated from the experimental thermochemical data of neutral and charged $\mathrm{H}_{2} \mathrm{SO}_{4} / \mathrm{H}_{2} \mathrm{O}$ cluster formation that are used in MAIA (Kazil and Lovejoy, 2007) compare well with neutral and charged $\mathrm{H}_{2} \mathrm{SO}_{4} / \mathrm{H}_{2} \mathrm{O}$ nucleation rates measured in the European Organization for Nuclear Research (CERN) Cosmics Leaving Outdoor Droplets (CLOUD) chamber (Kirkby et al., 2011). Global model simulations, using either a parameterization of neutral and charged $\mathrm{H}_{2} \mathrm{SO}_{4} / \mathrm{H}_{2} \mathrm{O}$ nucleation based on the CERN CLOUD chamber measurements or nucleation rates calculated from the experimental thermochemical data used in MAIA (Kazil et al., 2010), show a good agreement in the 


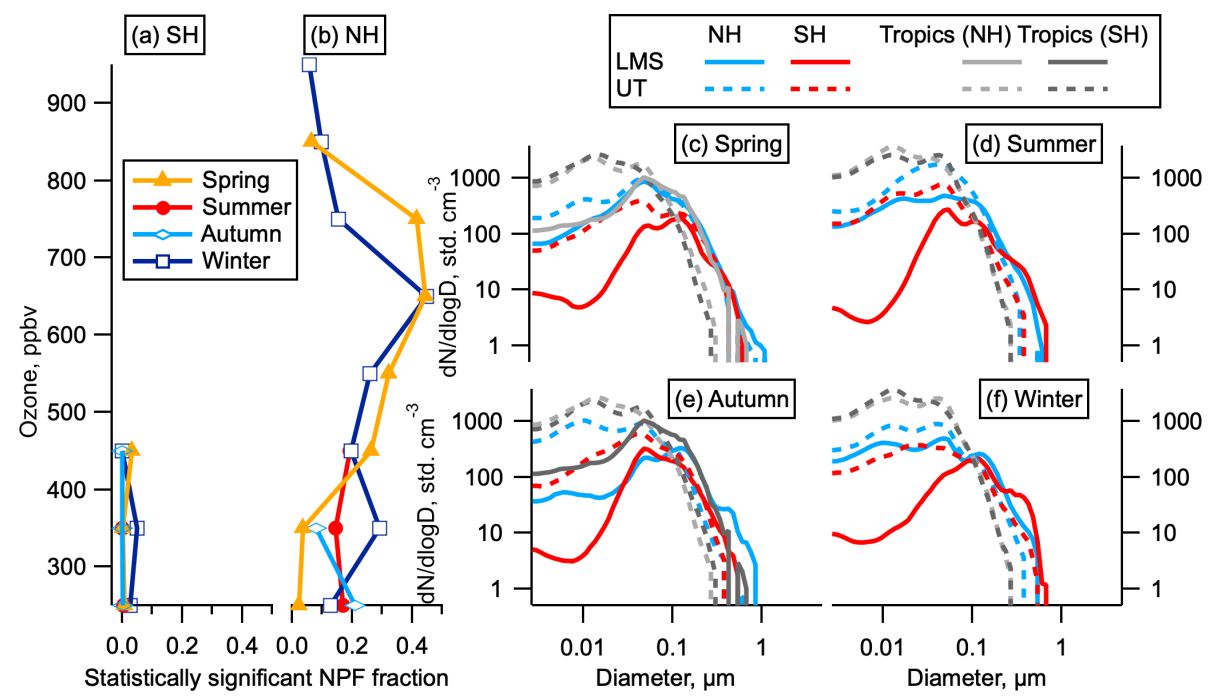

Figure 3. Statistically significant NPF and size distributions by hemisphere. (a, b) The fraction of data indicating statistically significant NPF as a function of ozone for each hemisphere and season. Data are limited to altitudes above $8 \mathrm{~km}$. (c-f) Average size distributions in the LMS and UT in the $\mathrm{NH}$ (latitudes above $30^{\circ}$ ), $\mathrm{SH}$ (latitudes below $-30^{\circ}$ ), and tropics $\left(-30\right.$ to $30^{\circ}$ ) by season. The LMS was not sampled in the tropics except in May. Tropics are shown both for the month corresponding to the NH season (dark grey) and the SH season (light grey); e.g. in spring the tropical May observations are shown in light grey and the tropical October observations are shown in dark grey.

global mean profile of total $(>3 \mathrm{~nm})$ aerosol concentration (Määttänen et al., 2018).

MAIA is run along back trajectories, initiated at the aircraft location, which were calculated using the Traj3D trajectory model (Bowman, 1993) and the National Center for Environmental Prediction (NCEP) global forecast system (GFS) meteorology (2015). NCEP provides temperature, relative humidity, and pressure along the trajectories for the MAIA runs. The initial $\mathrm{SO}_{2}$ concentration and the $\mathrm{H}_{2} \mathrm{SO}_{4}$ condensation sink of the initial aerosol size distribution were estimated from ATom observations at similar latitudes and altitudes. The geometric mean diameter $(46 \mathrm{~nm})$ and geometric standard deviation (2.8) of the initial aerosol size distribution were obtained by fitting a lognormal mode to the size distribution observed at the ATom measurement locations. The noon concentration of $\mathrm{OH}$ in the simulations was set to $3 \times 10^{6}$ molec. $\mathrm{cm}^{-3}$. This estimate agrees well with aircraft-measured $\mathrm{OH}$ concentrations during ATom (Kupc et al., 2020).

\section{More nucleation mode particles and $\mathrm{SO}_{2}$ are observed in the lowermost stratosphere in the Northern Hemisphere than in the Southern Hemisphere}

Our observations show that the total number of aerosol particles in the NH LMS is higher than in the SH LMS in all seasons (Fig. 2a-d). The elevated number of stratospheric particles in the NH relative to the $\mathrm{SH}$ persists for all submicron sizes but is largest at the smallest sizes (Fig. 2e). Analysis of number concentrations in the smallest observable size range shows statistically significant numbers of 3-7 nm particles relative to larger particles (see Sect. 2) (Williamson et al., 2019). This is the case for substantial portions of the LMS in all four seasons (Fig. 3a, b) in the NH but only for very small portions of the data in the $\mathrm{SH}$. These 3-7 nm particles have lifetimes in the NH LMS of just a few days (see Sect. S2). Particle number concentrations in the $\mathrm{NH}$ are between 4 and 100 times the SH concentrations in the LMS and between 2 and 9 times the $\mathrm{SH}$ concentrations in the UT, and the number concentration of nucleation mode particles is a larger fraction of the total aerosol number in the NH LMS than in the UT (Fig. 3c-f).

The majority of the aerosol surface area in the NH LMS is in the accumulation mode $(60-1000 \mathrm{~nm})$. While nucleation mode particles do not contribute substantially to the total aerosol surface area in the NH LMS, the Aitken mode $(12-60 \mathrm{~nm})$ can contribute around $10 \%$ of the total in the NH (Fig. 4). Newly formed particles that grow to these sizes will influence heterogeneous chemistry in the stratosphere, with potential implications for ozone depletion (Hofmann and Solomon, 1989). Aitken mode surface area is smaller in the SH LMS than in the NH LMS.

$\mathrm{SO}_{2}$ oxidation is a primary source of atmospheric $\mathrm{H}_{2} \mathrm{SO}_{4}$ in the gas phase, which readily participates in new particle formation and growth (Kuang et al., 2008; Kulmala et al., 2013). Measurements of $\mathrm{SO}_{2}$ mixing ratios with pptv sensitivity were made on the fourth ATom deployment in May 2018. Mixing ratios of $\mathrm{SO}_{2}$ in the $\mathrm{NH}$ LMS were several times higher than in the SH (Fig. 5a). Number concentrations of nucleation and Aitken mode particles show some correla- 


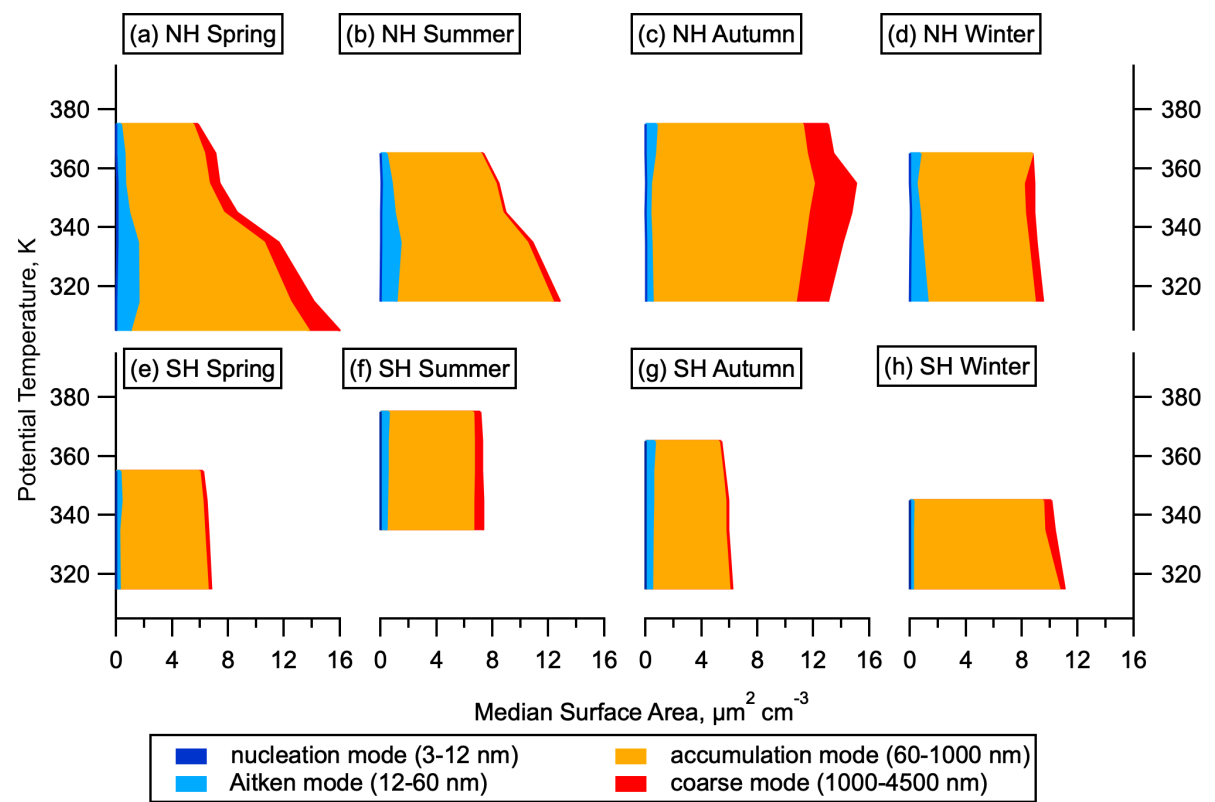

Figure 4. Aerosol surface area in the LMS. Aerosol surface area in the LMS as a function of potential temperature, separated by mode (colours) and season for the NH (a-d) and SH (e-h). Mode size ranges are 3-12 nm (nucleation), 12-60 nm (Aitken), 60-1000 nm (accumulation), and 1000-4500 $\mathrm{nm}$ (coarse).

tion with $\mathrm{SO}_{2}$, whereas number concentrations of accumulation and coarse mode particles show little to no correlation with $\mathrm{SO}_{2}$ (Fig. 6). This observed correlation between $\mathrm{SO}_{2}$ concentration and nucleation and Aitken mode particle concentrations suggests that the enhanced $\mathrm{SO}_{2}$ in the NH LMS is likely to be a precursor vapour for this NPF. We hypothesize that nucleation is occurring in the LMS, and the amount of condensable vapour available is one of the factors controlling the number of nucleation and Aitken mode particles produced.

\section{Observations and models suggest NPF occurs in the NH LMS}

We now turn our attention to the possibility of in situ NPF within the LMS. Concentrations of nucleation mode particles in the NH LMS are sometimes correlated with elevated $\mathrm{SO}_{2}$ in the NH LMS (Fig. 6), which is consistent with our understanding of $\mathrm{SO}_{2}$ as a precursor for NPF. While it is possible that nucleation in the NH LMS involves gas-phase species beyond sulfuric acid and water, the thermodynamics of binary nucleation in the sulfuric-acid-water system is still relevant. If it is possible to nucleate aerosol from just sulfuric acid and water (with or without ions), then the addition of gas-phase organics or ammonia will only make it easier.

We have conducted thermodynamic modelling of NPF for the temperature, pressure, and relative humidity observed in the NH LMS on ATom (see Sect. 2). This modelling indicates, for $\mathrm{H}_{2} \mathrm{SO}_{4}$ concentrations of $10^{6}$ molec. $\mathrm{cm}^{-3}$, whether it is energetically favourable for new particle formation via negative-ion-enhanced $\mathrm{H}_{2} \mathrm{SO}_{4}-\mathrm{H}_{2} \mathrm{O}$ nucleation to occur. Box modelling for $\mathrm{SO}_{2}$ concentrations similar to those observed in the NH LMS (20-40 pptv) shows this $\mathrm{H}_{2} \mathrm{SO}_{4}$ concentration is reasonable for the NH LMS but is likely too high for the SH LMS (Fig. 7). Figure 8 shows $\mathrm{SVP}_{\max } / p\left(\mathrm{H}_{2} \mathrm{SO}_{4}\right)$ values calculated at the $\mathrm{RH}_{\mathrm{w}}$ (relative humidity with respect to supersaturated water) and temperature conditions sampled by the aircraft for a fixed $p\left(\mathrm{H}_{2} \mathrm{SO}_{4}\right)$ level of $0.1 \mathrm{pptv}$, or approximately $10^{6}$ molec. $\mathrm{cm}^{-3}$ in the LMS $(300 \mathrm{hPa}, 220 \mathrm{~K})$. The highest altitudes sampled during ATom favoured nucleation of the negative ion-mediated binary system, including many of the LMS segments (little to no thermodynamic barrier to nucleation under these conditions). Neutral binary nucleation is always less favourable than the negative ion system, so calculated barriers for the negative ion system also denote barriers to the neutral system. This therefore indicates that NPF from sulfuric-acidwater is possible in the NH LMS.

Where LMS RH $\mathrm{RH}_{\mathrm{w}}$ was below about $1 \%-2 \%$, as in the $\mathrm{NH}$ in October 2017 and SH in February 2017 (Fig. S1), large thermodynamic barriers prohibited nucleation. Fewer nucleation mode particles were observed in the NH LMS in October than in other seasons (Fig. 2). No correlation is seen in the SH LMS between the occasional higher number concentrations of nucleation mode aerosol and $\mathrm{SO}_{2}$ (Fig. 6). This lack of correlation and the low concentrations of $\mathrm{SO}_{2}$ in the $\mathrm{SH}$ LMS suggest that if nucleation is sporadically occurring, or occurring at low rates, it is more likely to depend on species other than $\mathrm{H}_{2} \mathrm{SO}_{4}$. 

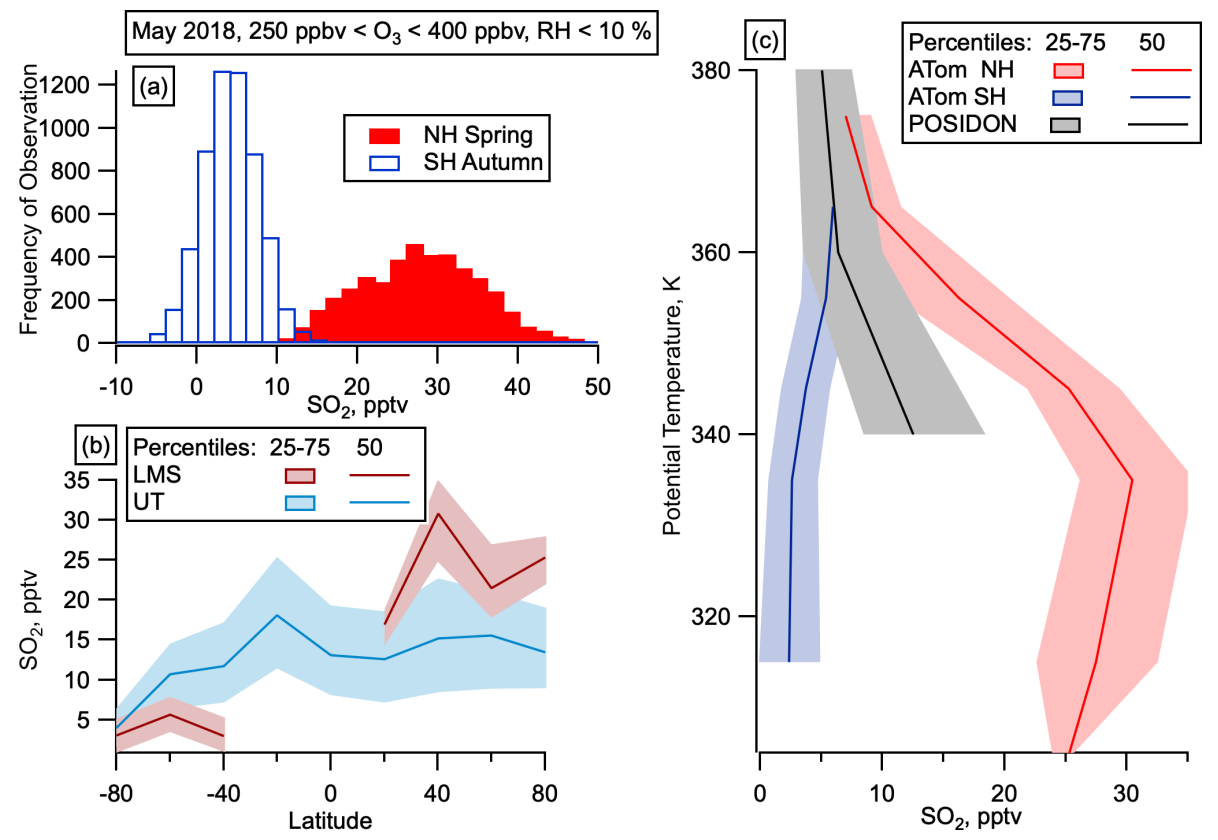

Figure 5. $\mathrm{SO}_{2}$ in the LMS. (a) Mixing ratios of gas-phase $\mathrm{SO}_{2}$ in the LMS (250 ppbv $<\mathrm{O}_{3}<400 \mathrm{ppbv}$ ) in the $\mathrm{SH}$ (open blue) and $\mathrm{NH}$ (filled red). (b) Median and interquartile range of $\mathrm{SO}_{2}$ by latitude in May for the LMS (red) and UT (Blue) in May. UT is defined as altitudes over $8 \mathrm{~km}$ and $\mathrm{O}_{3}<250 \mathrm{ppbv}$ or $\mathrm{RH}_{\mathrm{W}}>10 \%$. SO 2 observations at mixing ratios below 100 pptv are only available for the May 2018 deployment. (c) $\mathrm{SO}_{2}$ mixing ratios as a function of potential temperature from the tropical UT on POSIDON, October 2016, and from the LMS on ATom, May 2018.

Back trajectories from observations in the NH LMS in May show 35 out of the 55 trajectories we ran spend days prior to observation in low-relative-humidity stratospheric conditions (Fig. 7a-c). The other 20 trajectories experienced more humid air, indicative of UT or tropopause conditions. The box model MAIA shows that 20 pptv of $\mathrm{SO}_{2}$ (median observed $\mathrm{SO}_{2}$ values in the $\mathrm{NH}$ LMS in May were between 20 and 30 pptv, Fig. 5) produced $\mathrm{H}_{2} \mathrm{SO}_{4}$ on a diurnal cycle, with concentrations peaking between 0.5 and $1.5 \times 10^{6} \mathrm{~cm}^{-3}$ (Fig. 7d). The sulfuric acid production consistently causes nucleation to occur in the box model. Nucleation produced noticeable increases in nucleation mode number concentrations when either (i) starting $\mathrm{SO}_{2}$ concentrations were at or above 40 pptv or (ii) starting condensation sinks were at or below $1 \times 10^{-4} \mathrm{~s}^{-1}$ (Fig. $7 \mathrm{f}-\mathrm{h}$ ). We note that $40 \mathrm{pptv} \mathrm{SO}_{2}$ is higher than the median observed values in May in the $\mathrm{NH}$ LMS on ATom (Fig. 5), and observed condensation sinks were mostly above $1 \times 10^{-4} \mathrm{~s}^{-1}$ in this region (Fig. S2). In other seasons, the lower condensation sinks are closer to the modelled $1 \times 10^{-4} \mathrm{~s}^{-1}$ where binary nucleation produced noticeable concentrations of nucleation mode particles; however, we lack sensitive observations of $\mathrm{SO}_{2}$ in these seasons. $\mathrm{SO}_{2}$ concentrations in the model typically decrease by $\sim 20 \%$ over $24 \mathrm{~h}$ in these model runs, bringing mixing ratios fairly close to the observed concentrations within a few days.

The results from MAIA suggest that binary nucleation alone may be able to explain NPF in the NH LMS, although it is still possible that other condensable species contribute. Condensable organic vapours are likely present at mixing ratios on the order of pptv in the NH LMS (Murphy et al., 2020), which could increase rates of particle nucleation in the LMS (Gordon et al., 2016; Kupc et al., 2020). Previous studies have shown the likely role of condensable organics in the growth of newly formed particles in the tropical UT (Kupc et al., 2020), and it is conceivable that the low observed concentrations of organics in the NH LMS play a similar role. The case for involvement of condensable vapours beyond $\mathrm{H}_{2} \mathrm{SO}_{4}$ must not be overstated, however, as there are a number of uncertainties involved in modelling this phenomenon, including a lack of high-sensitivity $\mathrm{SO}_{2}$ measurements in three of the seasons.

Chamber studies have shown that the rate at which aerosols nucleate in the presence of sulfuric acid, water, and ammonia mixing ratios $>\sim 0.2$ pptv increases with the amount of ammonia at temperatures relevant to the LMS (208-223 K). At higher temperatures $(248 \mathrm{~K})$ this was also shown for even lower ammonia mixing ratios (Kürten et al., 2016). Single-particle composition measurements of particles with diameters between 350 and $600 \mathrm{~nm}$ show only slight neutralization of sulfate in the NH LMS, suggesting gas-phase mixing ratios of ammonia $<1$ pptv (Fig. S3). Larger concentrations of ammonia have been observed in the UT (Höpfner et al., 2016) but so far only in outflow from the Asian summer monsoon (ASM), which we did not de- 


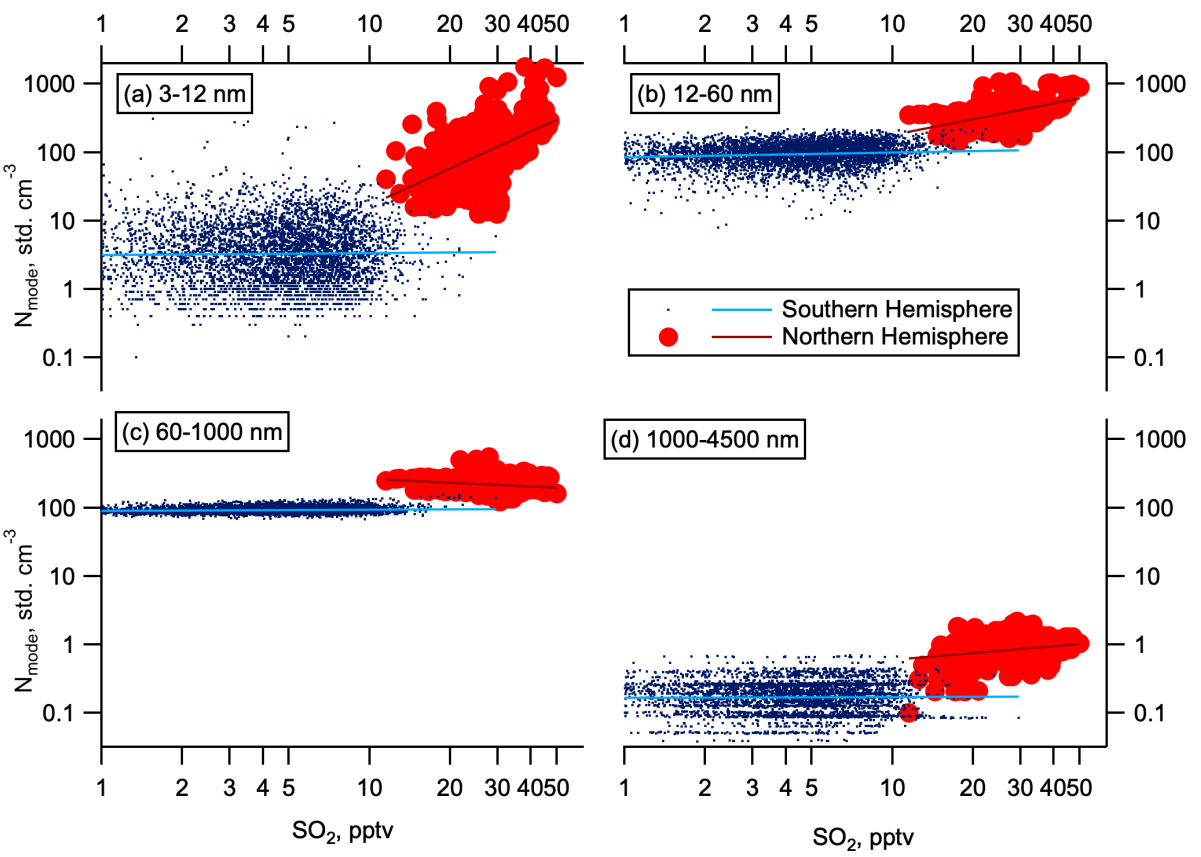

\begin{tabular}{|cllll|}
\hline (e) $\mathrm{R}^{2}$ values for $\log (\mathrm{N})$ to $\log \left(\mathrm{SO}_{2}\right)$ fits & & & \\
& & & & \\
Mode & Nucleation & Aitken & Accumulation & Coarse \\
$\mathrm{NH}$ & 0.313 & 0.324 & 0.060 & 0.049 \\
$\mathrm{SH}$ & 0.001 & 0.024 & 0.019 & 0.001 \\
\hline
\end{tabular}

Figure 6. Aerosol correlations with $\mathrm{SO}_{2}$. Number concentration dependence on $\mathrm{SO}_{2}$ at $0.1 \mathrm{~Hz}$ time resolution to reduce the effect of atmospheric and instrumental noise following Williamson et al. (2019). Number concentration as a function of $\mathrm{SO}_{2}$ mixing ratios in May (high-resolution $\mathrm{SO}_{2}$ data were not available in other seasons) for the Northern Hemisphere and Southern Hemisphere (red circles and blue dots respectively). Data are divided into four modes by size: (a) nucleation (3-12 nm), (b) Aitken (12-60 nm), (c) accumulation (60$1000 \mathrm{~nm}$ ), and (d) coarse (1000-4500). Log-log fits are given by the solid lines. Panel (e) shows $R^{2}$ values for these fits. Observations where $\mathrm{SO}_{2}$ is below the limit of detection (1 pptv) are not shown.

tect in the ATom observations. Therefore, we cannot exclude that ammonia may play a role in the NH LMS new particle formation observed on ATom. Even where the $\mathrm{SH}$ and $\mathrm{NH} \mathrm{SO}$ concentrations are similar, nucleation mode aerosol concentrations tend to be higher in the $\mathrm{NH}$ than in the $\mathrm{SH}$ (Fig. 6a). This suggests that species other than $\mathrm{H}_{2} \mathrm{SO}_{4}$ may also be more abundant in the NH LMS than the SH and play a role in nucleation and/or growth of aerosol. Similarly, we note that nucleation mechanisms that may be uncommon in the boundary layer, such as those including halogens or mercury, may be playing a role here but do not have the observations to test these ideas.

NPF is a highly non-linear process with respect to precursor concentrations. The regions containing LMS air measured on ATom were heterogeneous mixes of more stratosphere-like and more troposphere-like air. The increased production of nucleation mode particles in the higher- $\mathrm{RH}_{\mathrm{w}}$ cases in MAIA (Fig. 7f-h) means that we cannot rule out that NPF is preferentially taking place in more troposphere-like air in these regions, followed by transport/mixing on short timescales. While the bulk UT is ruled out as a source of the NH LMS nucleation mode particles in the arguments given in Sect. 5 below, and we would expect NPF occurring in more troposphere-like air to lead to higher concentrations of nucleation mode particles at lower potential temperatures, contrary to the observations shown in Fig. 9, observations of aerosol size distributions, chemical composition, and gas-phase precursors of NPF further above the tropopause are needed to completely rule out the influence of the UT on NPF in the NH LMS.

With regard to SH LMS observations of nucleation mode aerosol, while the concentrations were consistently lower than those observed in the NH LMS, concentrations between 125 and 175 std. $\mathrm{cm}^{-3}$ (per cubic centimetre at standard temperature and pressure, $273 \mathrm{~K}$ and $1013 \mathrm{hPa}$ respectively) were regularly observed in the SH LMS in all seasons (Fig. 2). These may also indicate NPF, albeit at a slower rate than in the NH. The slower rate is implied not only by the lower concentrations, but also by the longer lifetimes of nucleation mode particles in the LMS in the SH compared to the $\mathrm{NH}$ (Supplement Sect. S2), because of the lower concentrations of particles of all sizes observed here. Observations in the $\mathrm{SH}$ 

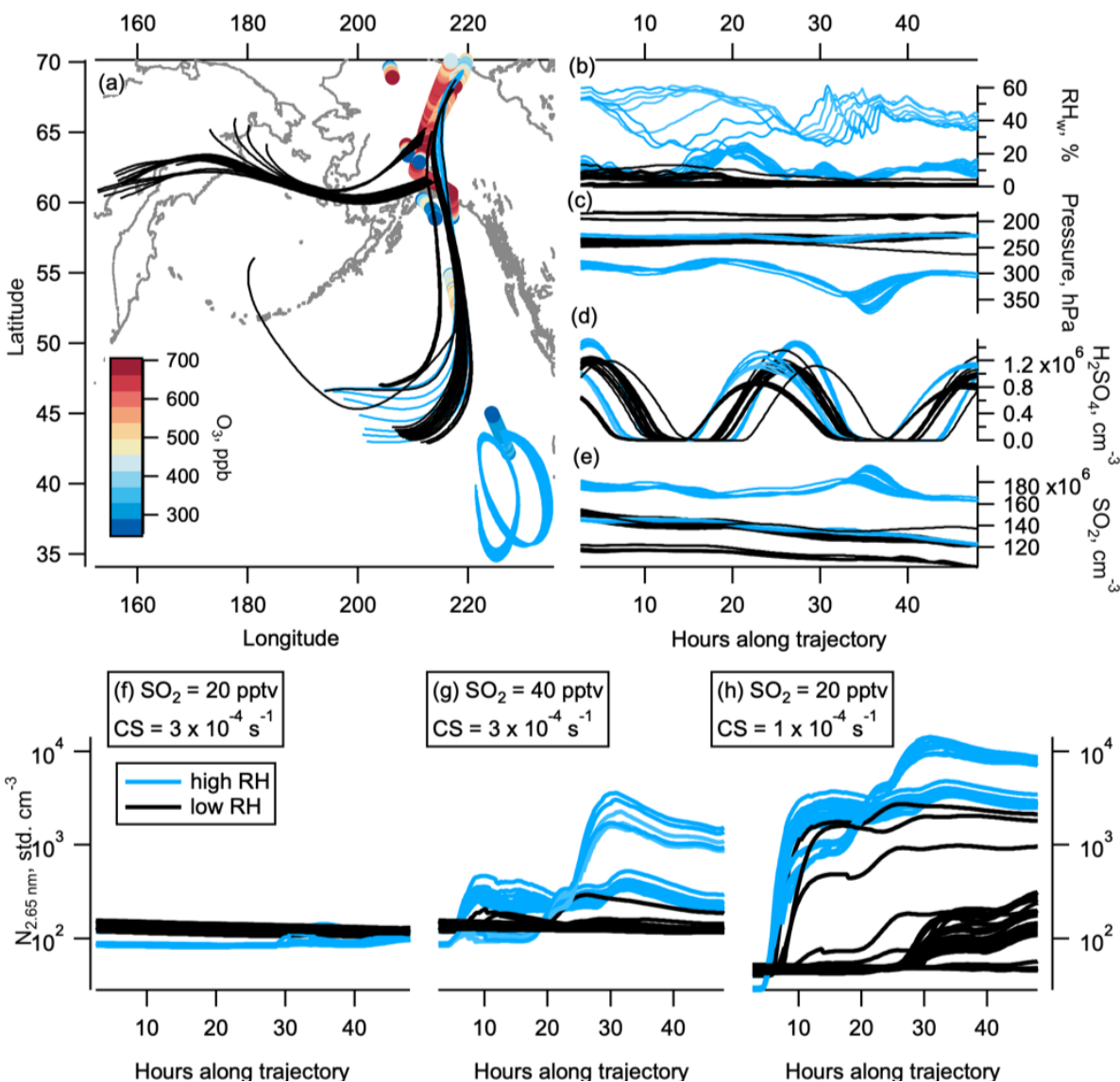

Figure 7. Box modelling and back trajectories. The $48 \mathrm{~h}$ back trajectories from selected observations in the NH LMS in May. Geographical location of back trajectories (lines) and observations (circles, coloured by ozone level) are shown in panel (a). Black lines are trajectories where the relative humidity $\left(\mathrm{RH}_{\mathrm{W}}\right)$ was mostly below $10 \%$, indicating stratospheric conditions. Light blue lines are trajectories where the $\mathrm{RH}_{\mathrm{W}}$ was often above $10 \%$, indicating tropospheric conditions. $\mathrm{RH}_{\mathrm{W}}$, pressure, sulfuric acid, and $\mathrm{SO}_{2}$ (from initial $20 \mathrm{pptv} \mathrm{SO}_{2}$ ) are shown in panels (b), (c), (d), and (e) respectively. Modelled number concentration of $2.7 \mathrm{~nm}$ particles on the high- $\mathrm{RH}_{\mathrm{W}}(\mathrm{blue})$ and low- $\mathrm{RH}_{\mathrm{W}}(\mathrm{black})$ trajectories are shown for the initial $20 \mathrm{pptv} \mathrm{SO}_{2}$ and starting condensation sink (CS) of $3 \times 10^{-4} \mathrm{~s}^{-1}$ (f), initial $40 \mathrm{pptv} \mathrm{SO}_{2}$ and starting condensation sink of $3 \times 10^{-4} \mathrm{~s}^{-1}(\mathbf{g})$, and initial $20 \mathrm{pptv} \mathrm{SO}$ and starting condensation sink of $1 \times 10^{-4} \mathrm{~s}^{-1}$ (h). The world map was made with Natural Earth free vector and raster map data, http://www.naturalearthdata.com (last access: 10 December 2015).

LMS did not extend to high enough altitudes to enable us to draw conclusions from the vertical structure.

\section{The observed nucleation mode particles and $\mathrm{SO}_{2}$ are not being transported into the NH LMS but rather being either formed in or directly emitted into this region}

The main potential transport routes for particles and $\mathrm{SO}_{2}$ into the NH LMS are transport from the tropics, either within the stratosphere from the tropical lower stratosphere or quasihorizontally across the tropopause from the tropical UT, vertical entrainment from the NH UT, downwelling from deeper in the stratosphere, and quasi-horizontal transport from the polar vortex in winter.

New particles have previously been shown to form in the tropical lower stratosphere and be transported northward in the stratosphere (Brock et al., 1995) and also to form in the tropical UT (Clarke et al., 1998, 2013; Clarke and Kapustin, 2002; Williamson et al., 2019) from where they could be transported quasi-horizontally across the tropopause into the NH LMS. Both of these transport pathways into the $\mathrm{NH}$ LMS occur on timescales of weeks to months or longer, which is inconsistent with the transport of newly formed particles, with lifetimes of a few days (Supplement Sect. S2, Figs. S4. S5, S6), from the tropics or NH UT into the NH LMS. Although quasi-isentropic transport on timescales less than a week has recently been observed in relation to extratropical cyclones and small-scale mixing (Kunkel et al., 2019), these small-scale phenomena are not frequent enough to produce the consistent elevated number concentrations of nucleation mode particles we observed in the NH LMS.

Transport from the tropics would lead to increased particle and $\mathrm{SO}_{2}$ concentrations in the LMS in both hemispheres, po- 

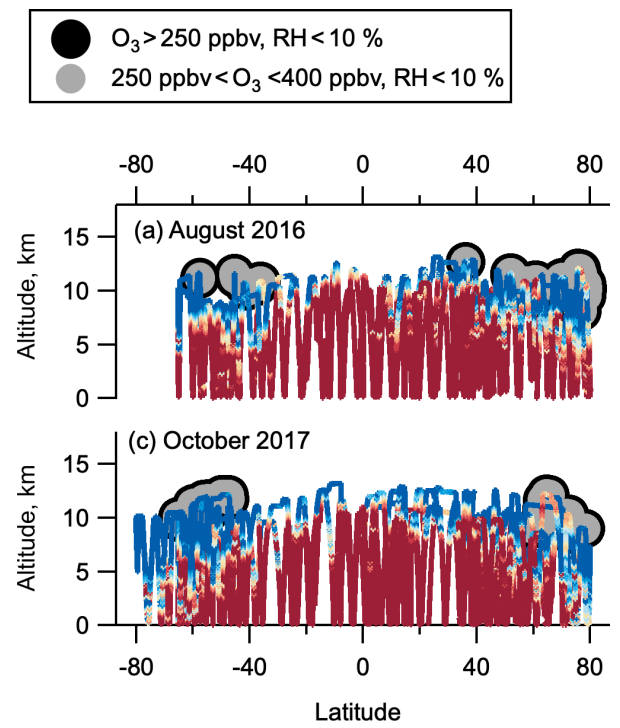
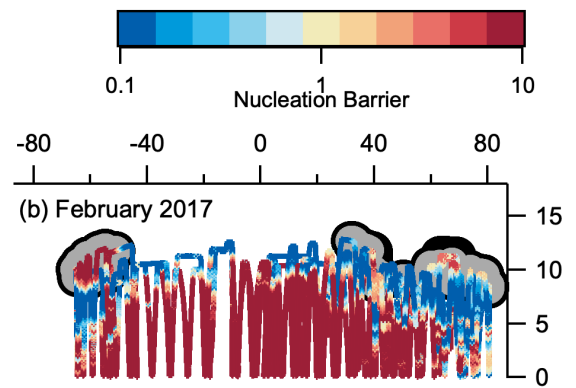

(d) May 2018

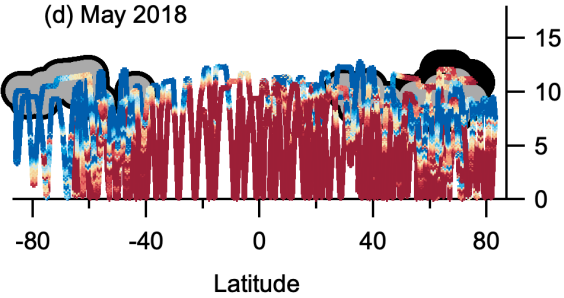

Figure 8. Thermodynamic barriers to nucleation. Thermodynamic nucleation barrier calculated of negative ion $\mathrm{H}_{2} \mathrm{SO}_{4}-\mathrm{H}_{2} \mathrm{O}$ clusters with $p\left(\mathrm{H}_{2} \mathrm{SO}_{4}\right)=0.1 \mathrm{pptv}$ for each season of ATom observation. Barrier values $\geq 10$ (dark red) are insurmountable, and negative ion $\mathrm{H}_{2} \mathrm{SO}_{4}-$ $\mathrm{H}_{2} \mathrm{O}$ NPF cannot occur. Barrier values $\leq 1$ (yellow-blue) mean that nucleation occurs unimpeded by a thermodynamic barrier if sufficient precursor vapour is present. Barrier between 1 and 10 (yellow-red) means nucleation can occur, but there is some thermodynamic barrier that needs to be overcome. Regions highlighted in grey have been identified as LMS $\left(250 \mathrm{ppbv}<\mathrm{O}_{3}<400 \mathrm{ppbv}, \mathrm{RH}_{\mathrm{W}}<10 \%\right)$.

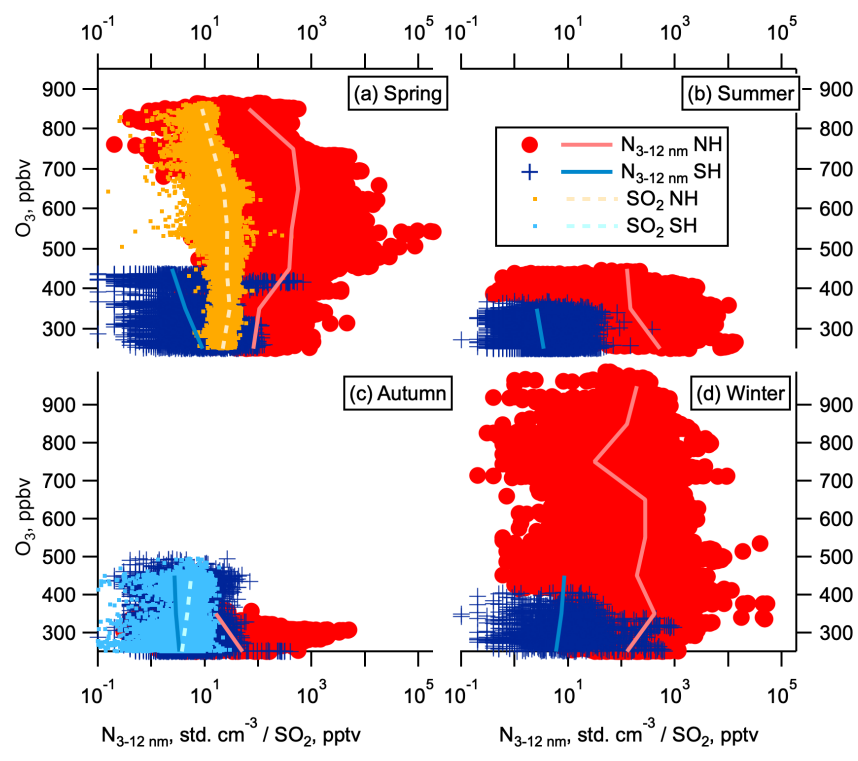

Figure 9. LMS aerosol and $\mathrm{SO}_{2}$ variation with ozone. Nucleation mode aerosol number concentration and $\mathrm{SO}_{2}$ concentration (shown only in May as this was not measured for other seasons) as a function of ozone in the LMS in each hemisphere for each season (a-d).

tentially with some enhancement in the summer hemisphere due to the location of the ITCZ (Vellinga and Wood, 2002; Chiang and Bitz, 2005; Broccoli et al., 2006). Since we only observed large numbers of nucleation mode particles in the LMS in the $\mathrm{NH}$ in all seasons, and $\mathrm{SO}_{2}$ observations in $\mathrm{NH}$ spring also showed much higher concentrations in the $\mathrm{NH}$ than the SH LMS, transport from the tropics cannot explain the observations. ATom observations in the tropics were not at high enough altitude to reach similar potential temperatures to those observed in the LMS at higher latitudes, but $\mathrm{SO}_{2}$ observations were taken at these potential temperatures in the tropics on the NASA POSIDON mission in October 2016 (Rollins et al., 2018). $\mathrm{SO}_{2}$ mixing ratios in the $\mathrm{NH}$ LMS are larger than those measured at similar potential temperatures in the tropical UT (Fig. 5c), which also makes it unlikely that the increased $\mathrm{NH}$ LMS $\mathrm{SO}_{2}$ was transported quasi-isentropically from the tropics.

Evidence suggests that entrainment from the NH UT at middle and high latitudes cannot explain the observed concentration and spatial distribution of $\mathrm{SO}_{2}$ in the $\mathrm{NH}$ LMS. The distribution of $\mathrm{SO}_{2}$ with potential temperature in the NH LMS (Fig. 5) shows the largest mixing ratios around $340 \mathrm{~K}$, with lower mixing ratios at lower potential temperature (correlating with lower altitude). This profile strongly argues against a tropospheric source and instead suggests direct emission of $\mathrm{SO}_{2}$ within the LMS.

Nucleation mode aerosols have been observed deep into the LMS $\left(\mathrm{O}_{3}>800 \mathrm{ppbv}\right)$ and not just close to the tropopause (Fig. 3). Because the lifetime of these particles is on the order of days, the enhanced abundance of these particles distant from the tropopause suggests that they have either formed in the LMS or been directly emitted in the LMS, rather than having been transported from the UT. In addition, the vertical profiles of nucleation mode particles and $\mathrm{SO}_{2}$ in the NH LMS are very different to the vertical profile of accumulation mode particles of tropospheric origin (Murphy et 


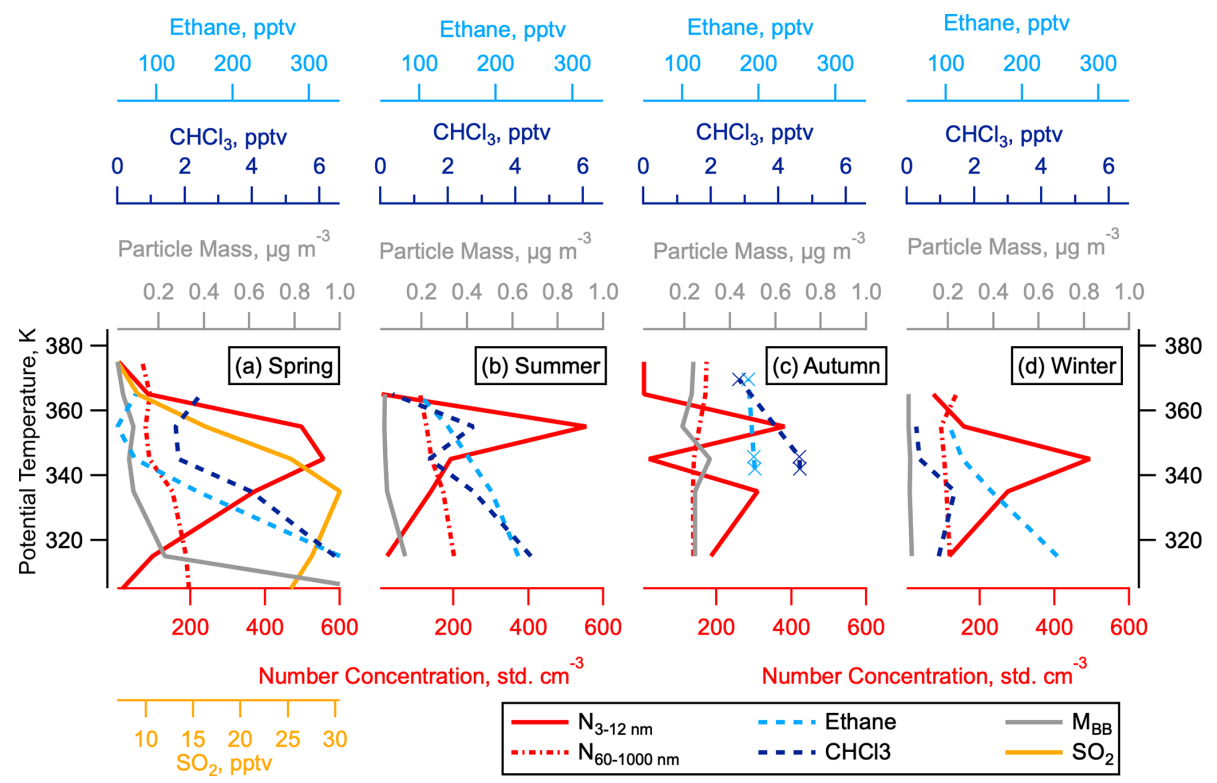

Figure 10. Vertical Profiles of nucleation mode particles and tropospheric tracers in the NH LMS. The 50th percentiles of number concentrations of nucleation mode $(3-12 \mathrm{~nm})$ and accumulation mode $(60-1000 \mathrm{~nm})$ particles, mass concentration of particles from biomass burning $\left(M_{\mathrm{BB}}\right)$, and concentrations of ethane and chloroform $\left(\mathrm{CHCl}_{3}\right)$, as a function of potential temperature in the NH LMS. The 50th percentile of the measured $\mathrm{SO}_{2}$ concentration is given in spring only, as these measurements were not taken in other seasons.

al., 2020) and other tracers of UT mixing, such as ethane and chloroform (both have tropospheric sources and lifetimes on the order of weeks to months (Parrish et al., 1992; Khalil et al., 1983), and particles from biomass burning (Fig. 10). This supports the argument that the nucleation mode particles and $\mathrm{SO}_{2}$ in the NH LMS are not a result of vertical transport from the midlatitude UT or horizontal transport from the tropics.

The vertical distributions of newly formed particles and $\mathrm{SO}_{2}$ are also evidence against downwards transport of $\mathrm{SO}_{2}$ from carbonyl sulfide (OCS) oxidation deeper in the stratosphere (Crutzen, 1976; Chin and Davis, 1995; Sheng et al., 2015; Brühl et al., 2012; Rollins et al., 2017). $\mathrm{O}_{3}$ concentrations increase in the stratosphere with distance from the tropopause; therefore, $\mathrm{O}_{3}$ is an effective tracer of depth of stratospheric air. If $\mathrm{SO}_{2}$ and the resulting nucleation mode particles were originating from OCS oxidation deep in the stratosphere, we would expect them to be correlated with $\mathrm{O}_{3}$. We do not observe $\mathrm{SO}_{2}$ increasing with $\mathrm{O}_{3}$ in the NH LMS (Fig. 9a) and therefore conclude that the $\mathrm{NH}$ excess $\mathrm{SO}_{2}$ is not from OCS oxidation. $\mathrm{SO}_{2}$ does increase with $\mathrm{O}_{3}$ in the SH LMS (Fig. 9c), suggesting OCS oxidation may be contributing to these lower, background levels of $\mathrm{SO}_{2}$.

$\mathrm{NPF}$ can take place in descending air in the polar vortex in winter, and quasi-horizontal transport is a potential pathway for these particles to then enter the LMS. However, similar to $\mathrm{SO}_{2}$, we do not observe nucleation mode particle concentrations increasing with $\mathrm{O}_{3}$ (Fig. 9), suggesting they do not originate deeper in the stratosphere. Furthermore, this pathway occurs only in winter, which does not explain the observed seasonal persistence of high nucleation mode aerosol in the
NH LMS, and should occur in both hemispheres, which is inconsistent with the observed hemispheric difference in LMS nucleation mode aerosol concentrations (Figs. 2, 3).

\section{Aircraft are the most likely source of nucleation mode particles in the NH LMS, either by direct emission of particles or emission of precursor vapours for NPF}

Air traffic is largely concentrated in the NH (Lee et al., 2010), and most emissions occur at $\sim 10 \mathrm{~km}$ altitude (Schröder et al., 2000). It has previously been observed that nucleation and Aitken mode particles are directly produced from aircraft (Brock et al., 2000; Kinsey et al., 2010), either as particles or forming from the gas phase immediately upon exiting the engine. Aircraft also directly emit $\mathrm{SO}_{2}$ into the atmosphere. Here we examine aircraft as a potential source of the observed elevated concentrations of nucleation mode aerosol, both through direct emissions and through NPF resulting from $\mathrm{SO}_{2}$ oxidation.

We use the Community Emissions Data System (CEDS) 2014 emissions database (Hoesly et al., 2018) to look at the global distribution and amount of $\mathrm{SO}_{2}$ emitted by aircraft in 2014 (Fig. 11). CEDS calculates aircraft emissions based on Lee et al. (2010) and Lamarque et al. (2010), which use $\mathrm{SO}_{2}$ emission indices between 0.6 and $1 \mathrm{~g} \mathrm{~kg}^{-1}$ fuel burned, with an average of $0.6 \mathrm{~g} \mathrm{~kg}^{-1}$. Global aircraft movements are taken from the AERO2K database (Eyers et al., 2004), with altitudes parameterized from statistical analysis 


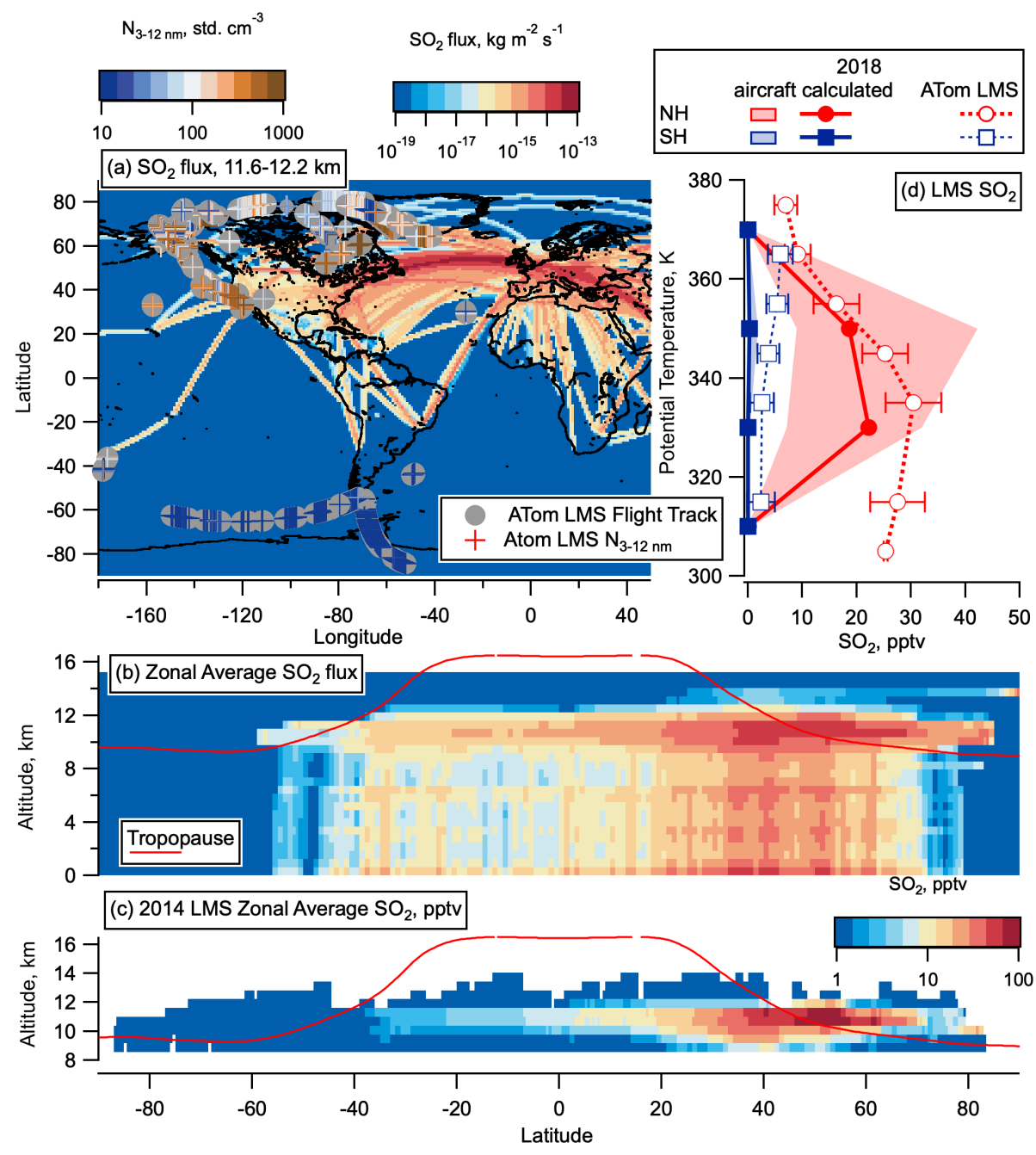

Figure 11. CEDS 2014 aircraft emissions $\mathrm{SO}_{2}$ flux and calculated LMS concentrations. (a) $\mathrm{SO}_{2}$ flux from aircraft from CEDS emissions database for May 2014, between 11.6 and $12.2 \mathrm{~km}$ altitude on a log-colour scale as a function of latitude and longitude, with ATom flight tracks from all seasons overlaid with LMS nucleation mode number concentration measurements coloured on a log scale for comparison. (b) $\mathrm{SO}_{2}$ flux (in $\mathrm{kg} \mathrm{m}^{-2} \mathrm{~s}^{-1}$ ) from aircraft from the CEDS emissions database zonally average for the whole year of 2014 as a function of altitude and latitude with the tropopause height from MERRA2 2014 in red. (c) Calculated, zonally averaged average $2014 \mathrm{SO}_{2}$ concentrations plotted on a logarithmic colour scale for altitudes $>8.5 \mathrm{~km}$ from these aircraft emissions, assuming a 1-month lifetime of $\mathrm{SO}_{2}$ in the $\mathrm{LMS}_{\text {, }}$ as a function of latitude and altitude with the tropopause height from MERRA2 2014 in red. (d) Median $\mathrm{SO}_{2}$ calculated as for (c) but scaled by a factor 1.23 to take into account increases in air traffic between 2014 and 2018 (Lee et al., 2020). MERRA2 data are used to convert CEDS emissions onto a potential temperature scale, and average profiles above $20^{\circ}$ latitude are compared with the median $\mathrm{ATom}_{\mathrm{LMS}} \mathrm{SO}_{2}$ observations in each hemisphere from May 2018. The 25-27th percentiles are given in shaded areas of the CEDS emissions, as well as error bars for ATom observations. The world map was made with Natural Earth free vector and raster map data, http://www.naturalearthdata.com (last access: 10 December 2015).

of air traffic data. Fuel consumption was calculated using the PIANO aircraft performance model and then scaled up to the International Energy Agency statistics of kerosene sales data to account for documented underestimates. We take the tropopause height from MERRA2 reanalysis temperatures in 2014.

Emission indices of particles with diameters between 3 and $10 \mathrm{~nm}$ (equivalent to our measured nucleation mode, 3 $12 \mathrm{~nm}$ ) in aircraft exhaust while cruising at $10.7 \mathrm{~km}$ have been measured as $\sim 10^{16}-10^{17}$ particles per kilogram of aircraft fuel for low-sulfur fuel (fuel sulfur content $=2.6 \mathrm{ppmm}$ (parts per million mass)) (Brock et al., 2000). We calculate that $19 \%$ of all aircraft $\mathrm{SO}_{2}$ emissions occurred in the $\mathrm{NH}$ between the tropopause and $13 \mathrm{~km}$ (this upper level is chosen to align with the maximum altitude of the ATom flights in order to relate the emissions directly to the observed regions) and $0.05 \%$ in the SH for the same region (Fig. 8), and we assume that particle emissions have a very similar spatial 


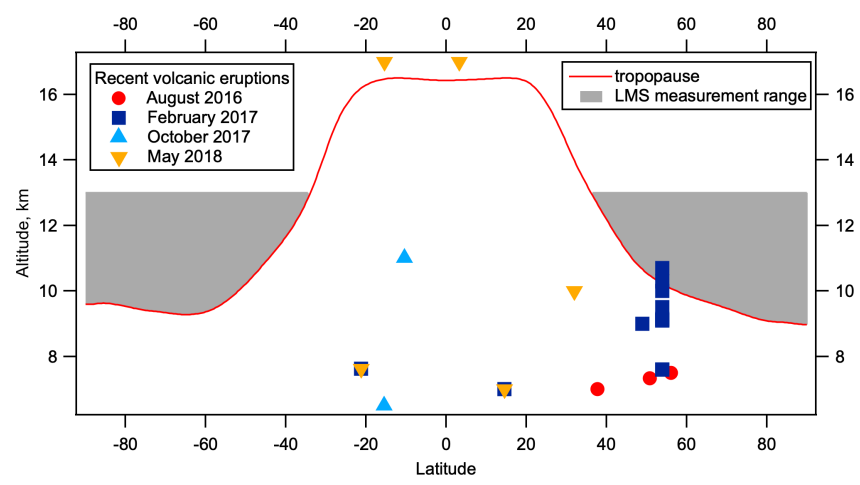

Figure 12. Volcanic eruptions within 2 months of ATom observations near the LMS. Volcanic eruptions plotted by latitude and plume altitude for 2 months prior to each ATom deployment where the plume altitude is above $7 \mathrm{~km}$. Eruptions are shown with colours/symbols corresponding to the relevant ATom deployment. Tropopause height as a function of latitude from 2014 MERRA2 data is shown in red, with the area between the tropopause and $13 \mathrm{~km}$ highlighted in grey. Details of these eruptions can be found in Table S1. Volcano data are from the Multi-Satellite Volcanic Sulfur Dioxide L4 Long-Term Global Database V4 (MSVOLSO2L4) (Carn, 2021).

distribution to $\mathrm{SO}_{2}$ emissions. Global aircraft fuel usage rate in 2018 was $327 \mathrm{Tg} \mathrm{yr}^{-1}$ (Lee et al., 2020), which, assuming the same spatial distribution in 2018 as in 2014, gives the maximum total number of nucleation mode particles emitted from aircraft in the NH and SH LMS of $626 \times 10^{25}$ and $1.74 \times 10^{25}$ respectively.

While particle lifetimes in non-plume LMS conditions are expected to be longer in the $\mathrm{SH}$ than the $\mathrm{NH}$, nucleation mode particle lifetimes within aircraft plumes have been shown to be around $2 \mathrm{~d}$ (Schröder et al., 2000). The plume and non-plume lifetimes in the NH LMS are similar enough to justify the use of a $2 \mathrm{~d}$ lifetime in this region (Supplement Sect. S2). In the SH LMS, there is a large difference between in-plume and non-plume lifetimes (from days to months). We use a $2 \mathrm{~d}$ lifetime here in the $\mathrm{SH}$ for illustrative purposes, but note that this is an underestimate, and thus the resulting concentration will represent an underestimate. Calculating the volume of the region defined above as the LMS to be $3.12 \times 10^{17}$ and $3.65 \times 10^{17} \mathrm{~m}^{3}$ for the $\mathrm{NH}$ and $\mathrm{SH}$, respectively, we get ambient concentrations of nucleation particles emitted by aircraft in the LMS of $110 \mathrm{~cm}^{-3}$ in the $\mathrm{NH}$ and a lower limit of $0.26 \mathrm{~cm}^{-3}$ in the SH. Taking an average temperature and pressure of $220 \mathrm{~K}$ and $300 \mathrm{hPa}$ for the LMS regions, and converting to standard temperature and pressure (STP), this gives maximum concentrations of $300 \mathrm{std} . \mathrm{cm}^{-3}$ for the $\mathrm{NH}$ and a lower limit of $0.71 \mathrm{std} . \mathrm{cm}^{-3}$ for the $\mathrm{SH}$. Minimum aircraft emissions of nucleation mode aerosol reported by Brock et al. (2000) are a factor of 10 lower than the maximum we have used here, leading to concentrations of 30 and $0.07 \mathrm{std} . \mathrm{cm}^{-3}$ for the $\mathrm{NH}$ and $\mathrm{SH}$ respectively.
The observed median nucleation mode aerosol concentrations in the NH LMS on ATom were between 50 and 600 std. $\mathrm{cm}^{-3}$ (Fig. 9), a similar order of magnitude to concentrations of nucleation mode particles calculated from aircraft emissions. Median observed nucleation mode particle concentrations in the SH LMS were between 2 and 10 std. $\mathrm{cm}^{-3}$ (Fig. 9). Since observed concentrations in the SH LMS are larger than concentrations calculated from aircraft emissions, this could imply a small additional source of nucleation mode aerosol, although a substantial uncertainty exists from the more varied lifetime in the SH between plume and non-plume conditions. Direct aircraft emissions are of a similar order of magnitude to the NH LMS enhancement observed on ATom. While within the large uncertainties of this comparison, the nucleation mode concentrations calculated from aircraft emissions are lower than the observed concentrations. This therefore does not discount the possibility of NPF occurring outside of aircraft plumes in the NH LMS as a result of elevated $\mathrm{SO}_{2}$ concentrations.

Figure 11a compares the spatial distribution of aircraft $\mathrm{SO}_{2}$ emissions in the NH LMS with the spatial distribution of nucleation mode number concentrations measured in the same region on ATom emissions. No obvious correlation between nucleation mode number concentrations and flight corridors is evident, with some of the highest nucleation mode number concentrations observed in the LMS around $1000 \mathrm{~km}$ away from flight corridors. Median zonal wind speeds encountered in the LMS on ATom were between 10 and $30 \mathrm{~m} \mathrm{~s}^{-1}$, with the 75th percentile of these wind speed between $\sim 20$ and $35 \mathrm{~m} \mathrm{~s}^{-1}$ (Fig. S7); therefore $1000 \mathrm{~km}$ is around half a day's transport from the flight corridor. Based on these measured wind speeds, zonal mixing is expected on timescales of around 1 month, which is approximately equal to the lifetime of $\mathrm{SO}_{2}$. However, since the jet core with peak wind speeds of $40-60 \mathrm{~m} \mathrm{~s}^{-1}$ is typically located on the tropopause in the $30-50^{\circ} \mathrm{N}$ region (Manney et al., 2014), and the peak in $\mathrm{SO}_{2}$ is also located in this region, the zonal mixing time could be as little as 1 to 2 weeks. For this reason, we present zonally averaged $\mathrm{SO}_{2}$ concentrations in Fig. 11b and c. Even with this fast, zonal transport, we might expect some correlation of number concentration with flight corridor locations, but airborne observations with denser sampling to compare highly trafficked with less trafficked regions in the $\mathrm{NH}$, and times around commercial flight times, would be needed to give a clearer picture of this. We hope that data from the In-Service Aircraft for a Global Observing System (IAGOS) program, which includes an instrument package measuring concentrations of particles with diameters $>13 \mathrm{~nm}$, will provide useful information from commercial aircraft when the data are made publicly available (Bundke et al., 2015).

From the global distributions of aircraft $\mathrm{SO}_{2}$ emissions from the CEDS database for 2014, we calculate the resulting $\mathrm{SO}_{2}$ concentration in the LMS, assuming a 1-month lifetime of $\mathrm{SO}_{2}$ in this region (see Sect. S2). Fast zonal mixing 
in the LMS, as evidenced above, is assumed in these calculations. An in-depth study of aircraft emissions shows a $23 \%$ increase in $\mathrm{SO}_{2}$ emissions between 2014 and 2018 (Lee et al., 2020); therefore, we multiply the calculated concentrations of $\mathrm{SO}_{2}$ from 2014 by a factor 1.23 to get the expected 2018 concentrations and compare these to ATom observations in the LMS as a function of potential temperature (Fig. 11d). Concentrations of observed $\mathrm{SO}_{2}$ in the $\mathrm{NH}$ LMS are very similar to the expected aircraft emissions and have a very similar vertical structure with a maximum occurring around $340 \mathrm{~K}$ in both emissions and observations. Emitted and observed $\mathrm{SO}_{2}$ concentrations in the $\mathrm{SH}$ LMS are very similar, although observed concentrations are consistently a few pptv higher. While this is certainly within the uncertainty of these calculations, higher observed concentrations compared with aircraft emissions in the SH LMS are also likely to indicate that while aviation emissions dominate in the $\mathrm{NH}$ where we see large amounts of air traffic, other sources of $\mathrm{SO}_{2}$ in the LMS exist and become apparent in the SH LMS where there is currently very little air traffic. Summing the 2014 zonal average $\mathrm{SO}_{2}$ flux, and multiplying by the surface area of each grid box and a factor 1.23 to update for 2018 air traffic, we determine a total flux of $0.279 \mathrm{Tg} \mathrm{yr}^{-1}$, with totals between the tropopause and $13 \mathrm{~km}$ in the $\mathrm{NH}$ and $\mathrm{SH}$ respectively of 0.066 and $0.000183 \mathrm{Tg} \mathrm{yr}^{-1}$.

Nonetheless, CEDS shows aircraft emissions capable of producing $\mathrm{SO}_{2}$ concentration in the LMS of similar orders of magnitude to those observed in ATom in both hemispheres, with the same striking hemispheric difference and the same vertical structure in the $\mathrm{NH}$. This strongly supports the argument that the observed elevated $\mathrm{SO}_{2}$ concentrations in the NH LMS are caused by emissions from aircraft. The consistency between measured $\mathrm{SO}_{2}$ mixing ratios and values calculated to be produced by aircraft emissions, together with the MAIA simulations along air parcel trajectories, implies that ion-assisted, binary homogeneous NPF in the NH LMS is a likely consequence of aircraft emissions.

In addition, we note that non-methane volatile organic compounds (NMVOCs) emitted from aircraft follow a similar distribution to $\mathrm{SO}_{2}$ from aircraft (Fig. S8). Even through the emitted flux of NMVOCs from aircraft is of a similar magnitude to $\mathrm{SO}_{2}$, we expect the steady-state mixing ratio of NMVOCs would be lower than that of $\mathrm{SO}_{2}$ because they likely have shorter lifetimes in LMS conditions (Balkanski et al., 1993; Tsigaridis et al., 2014). The co-emission of NMVOCs and $\mathrm{SO}_{2}$ from aircraft means aircraft are a potential source of two of the most likely species involved in aerosol nucleation and growth in the LMS, though we cannot at this stage quantify the fraction of condensable organic vapours observed by Murphy et al. (2020) in the NH LMS that can be accounted for by aircraft emissions.

\section{Other potential direct sources of nucleation mode particles and NPF precursors in the NH LMS}

Other candidates for direct emissions of nucleation mode particles and $\mathrm{SO}_{2}$ in the NH LMS are pyro-convection, the ASM, and volcanoes. Pyro-convection and the ASM are unlikely to contribute substantially for the following reasons:

1. Nucleation mode and biomass burning particles in the NH LMS did not follow the same trends with potential temperature (Fig. 10), which suggests that pyro-convection is not the major source of the nucleation mode particles we observed. In October, there is some indication in the vertical structure of nucleation mode number concentrations being suppressed at higher biomass burning particle mass concentrations and enhanced at lower biomass burning particle mass concentration. This suggests that the additional surface area from biomass burning particles may reduce nucleation mode number concentrations in the LMS through two mechanisms, suppressing the formation of particles by increasing the condensation sink and shortening the lifetime of particles that do form by increasing the coagulation sink.

2. While the ASM has been shown to be a source of $\mathrm{SO}_{2}$ and particulate matter in the NH LMS, this is true only during the monsoon season from June to September ( $\mathrm{Yu}$ et al., 2017). Since $\mathrm{SO}_{2}$ lifetime in the stratosphere is $\sim 1$ month (Sect. S2) and nucleation mode particle lifetimes are $\sim$ days, the enhancements observed on ATom in the $\mathrm{NH}$ in the fall, winter, and spring cannot have been from ASM outflow. ATom stratospheric observations did not see evidence of ASM-sourced particles (Murphy et al., 2020). Therefore, the ASM is not the cause of the observed NH LMS NPF.

No evidence of accumulation mode particles from volcanoes was observed in the NH LMS on ATom, except for in the $\mathrm{SH}$ in August (from the 2015 Calbuco eruption) (Murphy et al., 2020). The lifetime of nucleation mode particles is shorter than that of accumulation mode particles in the LMS (Sect. S2); therefore, there is no reason to suspect nucleation mode particles directly emitted from volcanoes would be present in the NH LMS during ATom observations. Volcanoes are, however, another potential source of direct injection of $\mathrm{SO}_{2}$ into the LMS.

Smaller volcanic eruptions are capable of injecting $\mathrm{SO}_{2}$ into the stratosphere. Eruptions contributing substantially to $\mathrm{SO}_{2}$ concentrations and insubstantially to accumulation mode particles that would have been detected as volcanic would occur between a few weeks and a couple of months from our measurements for each of the four deployments. Using data from the Multi-Satellite Volcanic Sulfur Dioxide L4 Long-Term Global Database V4 (MSVOLSO2L4) (Carn, 2021), we examine eruptions within 2 months leading up 
to each ATom deployment with peak plume heights above $7 \mathrm{~km}$ (Fig. 12, Table S1). Figure 12 shows the latitude and altitude of the recorded plume heights of these eruptions. While the vertical structure of volcanic emission plumes is complex, and such complexity is not accurately captured by the database used, or in general by satellite retrievals (Carn, 2021), we note that the only eruption to reach between the tropopause height (taken from the 2014 MERRA2 data) and $13 \mathrm{~km}$ (the upper limit of ATom observations), or within a few kilometres of these limits, is $2 \mathrm{~d}$ of the December 2016 Bogoslof eruption, totalling $0.0058 \mathrm{Tg} \mathrm{SO}_{2}$ in the NH LMS (Table $\mathrm{S} 1$ ). Total volcanic $\mathrm{SO}_{2}$ emissions above $7 \mathrm{~km}$ altitude within 2 months of observations, for ATom 1-4 respectively, were $0.057,0.0235,0$, and $0.048 \mathrm{Tg}$ in the $\mathrm{NH}$ and $0,0.002$, 0.08 , and $0.153 \mathrm{Tg}$ in the SH. The Aoba eruption in April 2018 was the largest eruption within this time frame, contributing $0.15 \mathrm{Tg}$ to the $\mathrm{SH}$, but the peak plume altitude was $17 \mathrm{~km}$, one of the highest recorded, which may reduce its influence on observations in the LMS which peaked at around $12 \mathrm{~km}$ in the SH in this season. Given the uncertainties in plume structure, it is not possible to estimate the effect these volcanic $\mathrm{SO}_{2}$ emissions had on the observed hemispheric differences in $\mathrm{LMS} \mathrm{SO}_{2}$ and nucleation mode particle concentrations. While it is true that ATom 3 saw the lowest $\mathrm{NH}$ volcanic $\mathrm{SO}_{2}$ emissions and the lowest $\mathrm{NH}$ nucleation mode particle number concentrations, in general the variation between seasons in the $\mathrm{NH}$ and the fact the $\mathrm{SH}$ emissions were larger than $\mathrm{NH}$ emission in ATom 3 and 4 suggest that this is unlikely to be the cause of seasonally persistent elevated nucleation mode particle concentrations in the NH LMS. This is supported by the lack of observations of volcanic aerosol of larger sizes in the NH LMS (Murphy et al., 2020), which places stringent limits on the timing of volcanic eruptions that can influence $\mathrm{SO}_{2}$ but not accumulation mode particles.

The uncertainties in volcanic emissions detailed above make any direct comparison of aircraft and volcanic $\mathrm{SO}_{2}$ sources in the LMS impossible, though it seems unlikely that the highly temporally variable $\mathrm{SO}_{2}$ recorded near the LMS from volcanoes could dominate over this strong, seasonally persistent aviation source over four seasons.

\section{Conclusions}

Within the scope of this study, the most likely cause of elevated numbers of nucleation mode aerosol in the NH LMS at mid- and high latitudes is aviation, through a combination of direction emission and nucleation in the exhaust plume, as well as NPF caused by elevated $\mathrm{SO}_{2}$ from aircraft in the background $\mathrm{NH}$ LMS. Known uncertainties in volcanic $\mathrm{SO}_{2}$ emissions, the effect on NMVOCs from aircraft, and sources of unusual NPF precursors such as halogens and mercury in the NH LMS remain potential causes of the observed hemispheric differences in nucleation mode aerosol concentrations that could not be fully ruled out. A refined bottom-up estimate of aircraft emissions and further in situ studies of both aircraft and volcanic emissions are essential to properly assess their contribution to the observed substantial nucleation mode aerosol concentrations and $\mathrm{SO}_{2}$ mixing ratios in the LMS of the NH.

Nucleation mode aerosols co-determine the size distribution particles in the LMS. Because of stratification of air density, most of the mass of the stratospheric aerosol, and hence its radiative effects, is in the LMS, although the mass mixing ratio of particles maximizes at altitudes $>20 \mathrm{~km}$ (Yu et al., 2016). If nucleation mode aerosols serve as sites for further condensational growth, they may shift the particle size distribution to smaller sizes in the LMS of the NH. In the LMS light scattering is driven by accumulation mode particles, and infrared heating is almost independent of particle size (Murphy et al., 2020). Therefore, a shift of the size distribution to smaller sizes may lead to more warming of the LMS compared to light scattering.

$\mathrm{SO}_{2}$ emissions from aircraft are increasing with time (Lee et al., 2020), and the expectation is for this trend to continue. Furthermore, alternative aircraft fuels are under consideration. Our results show that current levels of aviation have created substantially different conditions in the LMS in the NH compared with the less anthropogenically influenced $\mathrm{SH}$ and that the stratosphere system is sensitive to relatively small perturbations. This motivates further study of trace emissions from alternative aviation fuels, as well as targeted studies to reduce uncertainties on the stratospheric impacts of aviation currently. We hope these observations act as an early warning to fully understand the effect of aircraft emissions in the stratosphere before their magnitude increases further.

Climate intervention via injection of $\mathrm{SO}_{2}$ into the stratosphere is being discussed as a potential strategy to temporarily reduce the effects of anthropogenic greenhouse gases while their emissions are brought under control (Shepherd, 2012; Council, 2015; Keith et al., 2014; MacMartin and Kravitz, 2019). How this would be achieved and the potential consequences of such actions (both the intended effects and any unintended side effects) are highly uncertain. A more complete knowledge of the background state of the stratosphere and current anthropogenic influence in this region is needed before we can predict the effect of intentional modification on radiative balance, heterogenous chemistry, and circulation. The hemispheric difference in nucleation mode aerosol concentrations we have shown here is an example of how anthropogenic emissions are already modifying the stratosphere. This can be studied further to help understand the consequences of any intentional modification of stratospheric composition and must be considered in models used to design climate intervention strategies or assess their potential consequences. We must also be aware that any intentional stratospheric modification will be applied to two very different hemispheres: a largely pristine Southern Hemisphere and an already anthropogenically modified Northern Hemisphere. 
Data availability. The ATom dataset is published as Wofsy et al., (2018, https://doi.org/10.3334/ORNLDAAC/1581) and is also available at https://espoarchive.nasa.gov/archive/browse/atom (last access: December 2020, ESPO, 2020). POSIDON data are available at https://espoarchive.nasa.gov/archive/browse/posidon (last access: 6 January 2021, ESPO, 2021). Specific data and model outputs presented in this analysis are published as Williamson et al. (2021, https://doi.org/10.3334/ORNLDAAC/1868). Volcano data are from the Multi-Satellite Volcanic Sulfur Dioxide L4 Long-Term Global Database V4 (MSVOLSO2L4) described in Carn (2021) and are available at https://disc.gsfc.nasa.gov/datasets/ MSVOLSO2L4_3/summary (last access: November 2020). The CEDS emissions database is documented in Hoesly et al. (2017). MERRA2 data products can be obtained from https://disc.sci.gsfc. nasa.gov (last access: 3 January 2015, GMAO, 2015), and the 2014 zonally averaged tropopause heights and potential temperatures are included in the ORNL DAAC dataset related to this analysis.

Supplement. The supplement related to this article is available online at: https://doi.org/10.5194/acp-21-9065-2021-supplement.

Author contributions. Data collection and analysis on ATom were carried out by CJW, AK, and CAB (aerosol size distributions); AR $\left(\mathrm{SO}_{2}\right)$; KDF, GPS, and DMM (single-particle composition); JP, CT, IB, and TR (ozone); GSD and JPD (water vapour); TPB (meteorological and global positioning); DRB (trace gases); and MD and BW (cloud properties). POSIDON SO 2 data were collected by AR. EAR ran the ATom back trajectories. JK ran the MAIA box model, and KDF made the thermodynamic calculations. CJW wrote the manuscript, with input from all co-authors.

Competing interests. The authors declare that they have no conflict of interest.

Disclaimer. The contents do not necessarily represent the official views of the University of Colorado, the NOAA, the University of Vienna, or of the respective granting agencies. The use or mention of commercial products or services does not represent an endorsement by the authors or by any agency.

Acknowledgements. We thank Kenneth C. Aikin, Mathews Richardson, Huisheng Bian, James Wilson, and Duncan Axisa for contributions to this analysis, as well as the ATom leadership team, science team, and crew for contributions to the ATom measurements.

Financial support. This research has been supported by the National Aeronautics and Space Administration (grant nos. NNX15AJ23G and NNH15AB12I), the National Oceanic and Atmospheric Administration (Health of the Atmosphere and Atmospheric Chemistry, Carbon Cycle, and Climate Programs), the Aus- trian Science Fund (grant no. J-3613), and the European Research Council H2020 programme (grant no. A-LIFE (640458)).

Review statement. This paper was edited by Kostas Tsigaridis and reviewed by two anonymous referees.

\section{References}

Almeida, J., Schobesberger, S., Kurten, A., Ortega, I. K., Kupiainen-Maatta, O., Praplan, A. P., Adamov, A., Amorim, A., Bianchi, F., Breitenlechner, M., David, A., Dommen, J., Donahue, N. M., Downard, A., Dunne, E., Duplissy, J., Ehrhart, S., Flagan, R. C., Franchin, A., Guida, R., Hakala, J., Hansel, A., Heinritzi, M., Henschel, H., Jokinen, T., Junninen, H., Kajos, M., Kangasluoma, J., Keskinen, H., Kupc, A., Kurten, T., Kvashin, A. N., Laaksonen, A., Lehtipalo, K., Leiminger, M., Leppa, J., Loukonen, V., Makhmutov, V., Mathot, S., McGrath, M. J., Nieminen, T., Olenius, T., Onnela, A., Petaja, T., Riccobono, F., Riipinen, I., Rissanen, M., Rondo, L., Ruuskanen, T., Santos, F. D., Sarnela, N., Schallhart, S., Schnitzhofer, R., Seinfeld, J. H., Simon, M., Sipila, M., Stozhkov, Y., Stratmann, F., Tome, A., Trostl, J., Tsagkogeorgas, G., Vaattovaara, P., Viisanen, Y., Virtanen, A., Vrtala, A., Wagner, P. E., Weingartner, E., Wex, H., Williamson, C., Wimmer, D., Ye, P. L., Yli-Juuti, T., Carslaw, K. S., Kulmala, M., Curtius, J., Baltensperger, U., Worsnop, D. R., Vehkamaki, H., and Kirkby, J.: Molecular understanding of sulphuric acid-amine particle nucleation in the atmosphere, Nature, 502, 359-363, https://doi.org/10.1038/nature12663, 2013.

Baccarini, A., Karlsson, L., Dommen, J., Duplessis, P., Vüllers, J., Brooks, I. M., Saiz-Lopez, A., Salter, M., Tjernström, M., Baltensperger, U., Zieger, P., and Schmale, J.: Frequent new particle formation over the high Arctic pack ice by enhanced iodine emissions, Nat. Commun., 11, 4924, https://doi.org/10.1038/s41467020-18551-0, 2020.

Balkanski, Y. J., Jacob, D. J., Gardner, G. M., Graustein, W. C., and Turekian, K. K.: Transport and residence times of tropospheric aerosols inferred from a global three-dimensional simulation of ${ }^{210} \mathrm{~Pb}$, J. Geophys. Res.-Atmos., 98, 20573-20586, https://doi.org/10.1029/93JD02456, 1993.

Ball, S. M., Hanson, D. R., Eisele, F. L., and McMurry, P. H.: Laboratory studies of particle nucleation: Initial results for $\mathrm{H}_{2} \mathrm{SO}_{4}$, $\mathrm{H}_{2} \mathrm{O}$, and $\mathrm{NH}_{3}$ vapors, J. Geophys. Res.-Atmos., 104, 23709 23718, https://doi.org/10.1029/1999JD900411, 1999.

Bianchi, F., Trostl, J., Junninen, H., Frege, C., Henne, S., Hoyle, C. R., Molteni, U., Herrmann, E., Adamov, A., Bukowiecki, N., Chen, X., Duplissy, J., Gysel, M., Hutterli, M., Kangasluoma, J., Kontkanen, J., Kurten, A., Manninen, H. E., Munch, S., Perakyla, O., Petaja, T., Rondo, L., Williamson, C., Weingartner, E., Curtius, J., Worsnop, D. R., Kulmala, M., Dommen, J., and Baltensperger, U.: New particle formation in the free troposphere: A question of chemistry and timing, Science, 352, 1109-1112, https://doi.org/10.1126/science.aad5456, 2016.

Bianchi, F., Kurtén, T., Riva, M., Mohr, C., Rissanen, M. P., Roldin, P., Berndt, T., Crounse, J. D., Wennberg, P. O., Mentel, T. F., Wildt, J., Junninen, H., Jokinen, T., Kulmala, M., Worsnop, D. R., Thornton, J. A., Donahue, N., Kjaergaard, H. G., and Ehn, M.: Highly Oxygenated Organic Molecules (HOM) from Gas- 
Phase Autoxidation Involving Peroxy Radicals: A Key Contributor to Atmospheric Aerosol, Chem. Rev., 119, 3472-3509, https://doi.org/10.1021/acs.chemrev.8b00395, 2019.

Bourgeois, I., Peischl, J., Thompson, C. R., Aikin, K. C., Campos, T., Clark, H., Commane, R., Daube, B., Diskin, G. W., Elkins, J. W., Gao, R.-S., Gaudel, A., Hintsa, E. J., Johnson, B. J., Kivi, R., McKain, K., Moore, F. L., Parrish, D. D., Querel, R., Ray, E., Sánchez, R., Sweeney, C., Tarasick, D. W., Thompson, A. M., Thouret, V., Witte, J. C., Wofsy, S. C., and Ryerson, T. B.: Global-scale distribution of ozone in the remote troposphere from the ATom and HIPPO airborne field missions, Atmos. Chem. Phys., 20, 10611-10635, https://doi.org/10.5194/acp-2010611-2020, 2020.

Bowman, K. P.: Large-scale isentropic mixing properties of the Antarctic polar vortex from analyzed winds, J. Geophys. Res.Atmos., 98, 23013-23027, https://doi.org/10.1029/93jd02599, 1993.

Broccoli, A. J., Dahl, K. A., and Stouffer, R. J.: Response of the ITCZ to Northern Hemisphere cooling, Geophys. Res. Lett., 33, L01702, https://doi.org/10.1029/2005GL024546, 2006.

Brock, C. A., Hamill, P., Wilson, J. C., Jonsson, H. H., and Chan, K. R.: Particle Formation in the Upper Tropical Troposphere: A Source of Nuclei for the Stratospheric Aerosol, Science, 270, 1650-1653, https://doi.org/10.1126/science.270.5242.1650, 1995.

Brock, C. A., Schröder, F., Karcher, B., Petzold, A., Busen, R., and Fiebig, M.: Ultrafine particle size distributions measured in aircraft exhaust plumes, J. Geophys. Res.-Atmos., 105, 2655526567, https://doi.org/10.1029/2000jd900360, 2000.

Brock, C. A., Williamson, C., Kupc, A., Froyd, K. D., Erdesz, F., Wagner, N., Richardson, M., Schwarz, J. P., Gao, R.-S., Katich, J. M., Campuzano-Jost, P., Nault, B. A., Schröder, J. C., Jimenez, J. L., Weinzierl, B., Dollner, M., Bui, T., and Murphy, D. M.: Aerosol size distributions during the Atmospheric Tomography Mission (ATom): methods, uncertainties, and data products, Atmos. Meas. Tech., 12, 3081-3099, https://doi.org/10.5194/amt12-3081-2019, 2019.

Brühl, C., Lelieveld, J., Crutzen, P. J., and Tost, H.: The role of carbonyl sulphide as a source of stratospheric sulphate aerosol and its impact on climate, Atmos. Chem. Phys., 12, 1239-1253, https://doi.org/10.5194/acp-12-1239-2012, 2012.

Brühl, C., Lelieveld, J., Tost, H., Höpfner, M., and Glatthor, N.: Stratospheric sulfur and its implications for radiative forcing simulated by the chemistry climate model EMAC, J. Geophys. Res.Atmos., 120, 2103-2118, https://doi.org/10.1002/2014jd022430, 2015.

Bundke, U., Berg, M., Houben, N., Ibrahim, A., Fiebig, M., Tettich, F., Klaus, C., Franke, H., and Petzold, A.: The IAGOS-CORE aerosol package: instrument design, operation and performance for continuous measurement aboard in-service aircraft, Tellus B, 67, 28339, https://doi.org/10.3402/tellusb.v67.28339, 2015.

Campbell, P. and Deshler, T.: Condensation nuclei measurements in the midlatitude (1982-2012) and Antarctic (1986-2010) stratosphere between 20 and $35 \mathrm{~km}$, J. Geophys. Res.-Atmos., 119, 137-152, https://doi.org/10.1002/2013jd019710, 2014.

Carn, S.: Multi-Satellite Volcanic Sulfur Dioxide L4 Long-Term Global Database V4, Greenbelt, MD, USA, Goddard Earth Science Data and Information Services Center (GES DISC) [data set], https://doi.org/10.5067/MEASURES/SO2/DATA405, 2021.
Chan, K. R., Scott, S. G., Bui, T. P., Bowen, S. W., and Day, J.: Temperature and horizontal wind measurements on the ER-2 aircraft during the 1987 Airborne Antarctic Ozone Experiment, J. Geophys. Res.-Atmos., 94, 11573-11587, https://doi.org/10.1029/JD094iD09p11573, 1989.

Chiang, J. C. H. and Bitz, C. M.: Influence of high latitude ice cover on the marine Intertropical Convergence Zone, Clim. Dynam. 25, 477-496, https://doi.org/10.1007/s00382-005-0040-5, 2005.

Chin, M. and Davis, D. D.: A reanalysis of carbonyl sulfide as a source of stratospheric background sulfur aerosol, J. Geophys. Res.-Atmos., 100, 8993-9005, https://doi.org/10.1029/95JD00275, 1995.

Clarke, A. D. and Kapustin, V. N.: A Pacific aerosol survey, Part I: A decade of data on particle production, transport, evolution, and mixing in the troposphere, J. Atmos. Sci., 59, 363-382, https://doi.org/10.1175/15200469(2002)059<0363:Apaspi>2.0.Co;2, 2002.

Clarke, A. D. and Kapustin, V. N.: Hemispheric aerosol vertical profiles: Anthropogenic impacts on optical depth and cloud nuclei, Science, 329, 1488-1492, https://doi.org/10.1126/science.1188838, 2010.

Clarke, A. D., Varner, J. L., Eisele, F., Mauldin, R. L., Tanner, D., and Litchy, M.: Particle production in the remote marine atmosphere: Cloud outflow and subsidence during ACE 1, J. Geophys. Res.-Atmos., 103, 16397-16409, https://doi.org/10.1029/97jd02987, 1998.

Clarke, A. D., Eisele, F., Kapustin, V. N., Moore, K., Tanner, D., Mauldin, L., Litchy, M., Lienert, B., Carroll, M. A., and Albercook, G.: Nucleation in the equatorial free troposphere: Favorable environments during PEM-Tropics, J. Geophys. Res.Atmos., 104, 5735-5744, https://doi.org/10.1029/98jd02303, 1999.

Clarke, A. D., Freitag, S., Simpson, R. M. C., Hudson, J. G., Howell, S. G., Brekhovskikh, V. L., Campos, T., Kapustin, V. N., and Zhou, J.: Free troposphere as a major source of $\mathrm{CCN}$ for the equatorial pacific boundary layer: long-range transport and teleconnections, Atmos. Chem. Phys., 13, 7511-7529, https://doi.org/10.5194/acp-13-7511-2013, 2013.

Clegg, S. L., Rard, J. A., and Pitzer, K. S.: Thermodynamic properties of $0-6 \mu \mathrm{mol} \mathrm{kg} \mathrm{kg}^{-1}$ aqueous sulfuric acid from 273.15 to $328.15 \mathrm{~K}$, J. Chem. Soc. Faraday T., 90, 1875-1894, https://doi.org/10.1039/FT9949001875, 1994.

Colman, J. J., Swanson, A. L., Meinardi, S., Sive, B. C., Blake, D. R., and Rowland, F. S.: Description of the Analysis of a Wide Range of Volatile Organic Compounds in Whole Air Samples Collected during PEM-Tropics A and B, Anal. Chem., 73, 3723 3731, https://doi.org/10.1021/ac010027g, 2001.

Crutzen, P. J.: The possible importance of CSO for the sulfate layer of the stratosphere, Geophys. Res. Lett., 3, 73-76, https://doi.org/10.1029/GL003i002p00073, 1976.

Crutzen, P. J.: Albedo Enhancement by Stratospheric Sulfur Injections: A Contribution to Resolve a Policy Dilemma?, Climatic Change, 77, 211, https://doi.org/10.1007/s10584-006-9101-y, 2006.

Curtius, J., Froyd, K. D., and Lovejoy, E. R.: Cluster Ion Thermal Decomposition (I): Experimental Kinetics Study and ab Initio Calculations for $\mathrm{HSO}_{4}^{-}\left(\mathrm{H}_{2} \mathrm{SO}_{4}\right)_{x}\left(\mathrm{HNO}_{3}\right)_{y}$, J. Phys. Chem. A, 105, 10867-10873, https://doi.org/10.1021/jp0124950, 2001. 
Dada, L., Paasonen, P., Nieminen, T., Buenrostro Mazon, S., Kontkanen, J., Peräkylä, O., Lehtipalo, K., Hussein, T., Petäjä, T., Kerminen, V.-M., Bäck, J., and Kulmala, M.: Long-term analysis of clear-sky new particle formation events and nonevents in Hyytiälä, Atmos. Chem. Phys., 17, 6227-6241, https://doi.org/10.5194/acp-17-6227-2017, 2017.

Damoah, R., Spichtinger, N., Servranckx, R., Fromm, M., Eloranta, E. W., Razenkov, I. A., James, P., Shulski, M., Forster, C., and Stohl, A.: A case study of pyro-convection using transport model and remote sensing data, Atmos. Chem. Phys., 6, 173185, https://doi.org/10.5194/acp-6-173-2006, 2006.

Diskin, G. S. and DiGangi, J. P.: ATom: L2 in situ atmospheric water vapor from the Diode Laser Hygrometer (DLH), ORNL DAAC, Oak Ridge, Tennessee, USA, https://doi.org/10.3334/ORNLDAAC/1710, 2019.

Diskin, G. S., Podolske, J. R., Sachse, G. W., and Slate, T. A.: Open-path airborne tunable diode laser hygrometer, Diode Lasers and Applications in Atmospheric Sensing, 4817, 196204, https://doi.org/10.1117/12.453736, 2002.

Ditas, J., Ma, N., Zhang, Y., Assmann, D., Neumaier, M., Riede, H., Karu, E., Williams, J., Scharffe, D., Wang, Q., Saturno, J., Schwarz, J. P., Katich, J. M., McMeeking, G. R., Zahn, A., Hermann, M., Brenninkmeijer, C. A. M., Andreae, M. O., Pöschl, U., Su, H., and Cheng, Y.: Strong impact of wildfires on the abundance and aging of black carbon in the lowermost stratosphere, P. Natl. Acad. Sci. USA, 115, 11595-11603, https://doi.org/10.1073/pnas.1806868115, 2018.

Dix, B., Baidar, S., Bresch, J. F., Hall, S. R., Schmidt, K. S., Wang, S., and Volkamer, R.: Detection of iodine monoxide in the tropical free troposphere, P. Natl. Acad. Sci. USA, 110, 2035-2040, https://doi.org/10.1073/pnas.1212386110, 2013.

Duplissy, J., Merikanto, J., Franchin, A., Tsagkogeorgas, G., Kangasluoma, J., Wimmer, D., Vuollekoski, H., Schobesberger, S., Lehtipalo, K., Flagan, R. C., Brus, D., Donahue, N. M., Vehkamäki, H., Almeida, J., Amorim, A., Barmet, P., Bianchi, F., Breitenlechner, M., Dunne, E. M., Guida, R., Henschel, H., Junninen, H., Kirkby, J., Kürten, A., Kupc, A., Määttänen, A., Makhmutov, V., Mathot, S., Nieminen, T., Onnela, A., Praplan, A. P., Riccobono, F., Rondo, L., Steiner, G., Tome, A., Walther, H., Baltensperger, U., Carslaw, K. S., Dommen, J., Hansel, A., Petäjä, T., Sipilä, M., Stratmann, F., Vrtala, A., Wagner, P. E., Worsnop, D. R., Curtius, J., and Kulmala, M.: Effect of ions on sulfuric acid-water binary particle formation: 2 . Experimental data and comparison with QC-normalized classical nucleation theory, J. Geophys. Res.-Atmos., 121, 1752-1775, https://doi.org/10.1002/2015jd023539, 2016.

Easter, R. C. and Peters, L. K.: Binary Homogeneous Nucleation: Temperature and Relative Humidity Fluctuations, Nonlinearity, and Aspects of New Particle Production in the Atmosphere, J. Appl. Meteorol. Clim., 33, 775-784, https://doi.org/10.1175/15200450(1994)033<0775:Bhntar>2.0.Co;2, 1994.

Earth Science Project Office (ESPO): NASA Atom ESPO data archive, available at: https://espoarchive.nasa.gov/archive/ browse/atom, last access: 11 December 2020.

Earth Science Project Office (ESPO): NASA POSIDON ESPO data archive, available at: https://espoarchive.nasa.gov/archive/ browse/posidon, last access: 6 January 2021.
Eyers, C. J., Norman, P., Middel, J., Plohr, M., Michot, S., Atkinson, K., and Christou, R. A.: AERO2k Global Aviation Emissions Inventories for 2002 and 2025, QinetiQ for Dr-Ing Dietrich Knoerzer, European Commission under Contract No. G4RD-CT2000-00382 QinetiQ Limited, Cody Technology Park, Farnborough, Hampshire GU14 0LX, UK, 2004.

Fromm, M. D. and Servranckx, R.: Transport of forest fire smoke above the tropopause by supercell convection, Geophys. Res. Lett., 30, 1542, https://doi.org/10.1029/2002g1016820, 2003.

Froyd, K. D. and Lovejoy, E. R.: Experimental Thermodynamics of Cluster Ions Composed of $\mathrm{H}_{2} \mathrm{SO}_{4}$ and $\mathrm{H}_{2} \mathrm{O}$, 1. Positive Ions, J. Phys. Chem. A, 107, 9800-9811, https://doi.org/10.1021/jp027803o, 2003.

Froyd, K. D. and Lovejoy, E. R.: Bond Energies and Structures of Ammonia-Sulfuric Acid Positive Cluster Ions, J. Phys. Chem. A, 116, 5886-5899, https://doi.org/10.1021/jp209908f, 2012.

Froyd, K. D., Murphy, D. M., Brock, C. A., Campuzano-Jost, P., Dibb, J. E., Jimenez, J.-L., Kupc, A., Middlebrook, A. M., Schill, G. P., Thornhill, K. L., Williamson, C. J., Wilson, J. C., and Ziemba, L. D.: A new method to quantify mineral dust and other aerosol species from aircraft platforms using singleparticle mass spectrometry, Atmos. Meas. Tech., 12, 6209-6239, https://doi.org/10.5194/amt-12-6209-2019, 2019.

Gaines, S. E., Bowen, S. W., Hipskind, R. S., Bui, T. P., and Chan, K. R.: Comparisons of the NASA ER-2 Meteorological Measurement System with Radar Tracking and Radiosonde Data, J. Atmos. Ocean. Tech., 9, 210-225, https://doi.org/10.1175/15200426(1992)009<0210:Cotnem>2.0.Co;2, 1992.

Giauque, W. F., Hornung, E. W., Kunzler, J. E., and Rubin, T. R.: The Thermodynamic Properties of Aqueous Sulfuric Acid Solutions and Hydrates from 15 to $300^{\circ} \mathrm{K}^{1}$, J. Am. Chem. Soc., 82, 62-70, https://doi.org/10.1021/ja01486a014, 1960.

Gordon, H., Sengupta, K., Rap, A., Duplissy, J., Frege, C., Williamson, C., Heinritzi, M., Simon, M., Yan, C., Almeida, J., Trostl, J., Nieminen, T., Ortega, I. K., Wagner, R., Dunne, E. M., Adamov, A., Amorim, A., Bernhammer, A. K., Bianchi, F., Breitenlechner, M., Brilke, S., Chen, X. M., Craven, J. S., Dias, A., Ehrhart, S., Fischer, L., Flagan, R. C., Franchin, A., Fuchs, C., Guida, R., Hakala, J., Hoyle, C. R., Jokinen, T., Junninen, H., Kangasluoma, J., Kim, J., Kirkby, J., Krapf, M., Kurten, A., Laaksonen, A., Lehtipalo, K., Makhmutov, V., Mathot, S., Molteni, U., Monks, S. A., Onnela, A., Perakyla, O., Piel, F., Petaja, T., Praplanh, A. P., Pringle, K. J., Richards, N. A. D., Rissanen, M. P., Rondo, L., Sarnela, N., Schobesberger, S., Scott, C. E., Seinfeldo, J. H., Sharma, S., Sipila, M., Steiner, G., Stozhkov, Y., Stratmann, F., Tome, A., Virtanen, A., Vogel, A. L., Wagner, A. C., Wagner, P. E., Weingartner, E., Wimmer, D., Winkler, P. M., Ye, P. L., Zhang, X., Hansel, A., Dommen, J., Donahue, N. M., Worsnop, D. R., Baltensperger, U., Kulmala, M., Curtius, J., and Carslaw, K. S.: Reduced anthropogenic aerosol radiative forcing caused by biogenic new particle formation, P. Natl. Acad. Sci. USA, 113, 12053-12058, https://doi.org/10.1073/pnas.1602360113, 2016.

Gordon, H., Kirkby, J., Baltensperger, U., Bianchi, F., Breitenlechner, M., Curtius, J., Dias, A., Dommen, J., Donahue, N. M., Dunne, E. M., Duplissy, J., Ehrhart, S., Flagan, R. C., Frege, C., Fuchs, C., Hansel, A., Hoyle, C. R., Kulmala, M., Kurten, A., Lehtipalo, K., Makhmutov, V., Molteni, U., Rissanen, M. P., Stozkhov, Y., Trostl, J., Tsagkogeor- 
gas, G., Wagner, R., Williamson, C., Wimmer, D., Winkler, P. M., Yan, C., and Carslaw, K. S.: Causes and importance of new particle formation in the present-day and preindustrial atmospheres, J. Geophys. Res.-Atmos., 122, 8739-8760, https://doi.org/10.1002/2017jd026844, 2017.

Global Modeling and Assimilation Office (GMAO): MERRA-2 instM_3d_asm_Np: 3d, monthly mean, instantaneous, pressurelevel, assimilation, assimilated Meteorological Fields V5.12.4, Greenbelt, MD, USA, Goddard Earth Sciences Data and Information Services Center (GES DISC), available at: https://disc. sci.gsfc.nasa.gov, last access: 3 January 2015.

Hanson, D. R. and Lovejoy, E. R.: Measurement of the Thermodynamics of the Hydrated Dimer and Trimer of Sulfuric Acid, J. Phys. Chem. A, 110, 9525-9528, https://doi.org/10.1021/jp062844w, 2006.

Hoesly, R. M., Smith, S. J., Feng, L., Klimont, Z., JanssensMaenhout, G., Pitkanen, T., Seibert, J. J., Vu, L., Andres, R. J., Bolt, R. M., Bond, T. C., Dawidowski, L., Kholod, N., Kurokawa, J.-I., Li, M., Liu, L., Lu, Z., Moura, M. C. P., O'Rourke, P. R., and Zhang, Q.: Historical (1750-2014) anthropogenic emissions of reactive gases and aerosols from the Community Emissions Data System (CEDS), Geosci. Model Dev., 11, 369-408, https://doi.org/10.5194/gmd-11-369-2018, 2018.

Hofmann, D., Barnes, J., O’Neill, M., Trudeau, M., and Neely, R.: Increase in background stratospheric aerosol observed with lidar at Mauna Loa Observatory and Boulder, Colorado, Geophys. Res. Lett., 36, L15808, https://doi.org/10.1029/2009g1039008, 2009.

Hofmann, D. J. and Solomon, S.: Ozone destruction through heterogeneous chemistry following the eruption of El Chichon, J. Geophys. Res.-Atmos., 94, 5029-5041, https://doi.org/10.1029/JD094iD04p05029, 1989.

Höpfner, M., Volkamer, R., Grabowski, U., Grutter, M., Orphal, J., Stiller, G., von Clarmann, T., and Wetzel, G.: First detection of ammonia $\left(\mathrm{NH}_{3}\right)$ in the Asian summer monsoon upper troposphere, Atmos. Chem. Phys., 16, 14357-14369, https://doi.org/10.5194/acp-16-14357-2016, 2016.

Humphries, R. S., Schofield, R., Keywood, M. D., Ward, J., Pierce, J. R., Gionfriddo, C. M., Tate, M. T., Krabbenhoft, D. P., Galbally, I. E., Molloy, S. B., Klekociuk, A. R., Johnston, P. V., Kreher, K., Thomas, A. J., Robinson, A. D., Harris, N. R. P., Johnson, R., and Wilson, S. R.: Boundary layer new particle formation over East Antarctic sea ice - possible Hg-driven nucleation?, Atmos. Chem. Phys., 15, 13339-13364, https://doi.org/10.5194/acp-15-13339-2015, 2015.

Kazil, J. and Lovejoy, E. R.: A semi-analytical method for calculating rates of new sulfate aerosol formation from the gas phase, Atmos. Chem. Phys., 7, 3447-3459, https://doi.org/10.5194/acp7-3447-2007, 2007.

Kazil, J., Lovejoy, E. R., Jensen, E. J., and Hanson, D. R.: Is aerosol formation in cirrus clouds possible?, Atmos. Chem. Phys., 7, 1407-1413, https://doi.org/10.5194/acp-7-1407-2007, 2007.

Kazil, J., Stier, P., Zhang, K., Quaas, J., Kinne, S., O’Donnell, D., Rast, S., Esch, M., Ferrachat, S., Lohmann, U., and Feichter, J.: Aerosol nucleation and its role for clouds and Earth's radiative forcing in the aerosol-climate model ECHAM5-HAM, Atmos. Chem. Phys., 10, 10733-10752, https://doi.org/10.5194/acp-1010733-2010, 2010.
Keith, D. W., Duren, R., and MacMartin, D. G.: Field experiments on solar geoengineering: report of a workshop exploring a representative research portfolio, Philos. T. Roy. Soc. A, 372, 20140175, https://doi.org/10.1098/rsta.2014.0175, 2014.

Kerminen, V.-M., Chen, X., Vakkari, V., Petäjä, T., Kulmala, M., and Bianchi, F.: Atmospheric new particle formation and growth: review of field observations, Environ. Res. Lett., 13, 103003, https://doi.org/10.1088/1748-9326/aadf3c, 2018.

Khalil, M. A. K., Rasmussen, R. A., and Hoyt, S. D.: Atmospheric chloroform $\left(\mathrm{CHCl}_{3}\right)$ : Ocean-air exchange and global mass balance, Tellus B, 35, 266-274, https://doi.org/10.3402/tellusb.v35i4.14614, 1983.

Kinsey, J. S., Dong, Y., Williams, D. C., and Logan, R.: Physical characterization of the fine particle emissions from commercial aircraft engines during the Aircraft Particle Emissions eXperiment (APEX) 1-3, Atmos. Environ., 44, 2147-2156, https://doi.org/10.1016/j.atmosenv.2010.02.010, 2010.

Kirkby, J., Curtius, J., Almeida, J., Dunne, E., Duplissy, J., Ehrhart, S., Franchin, A., Gagné, S., Ickes, L., Kürten, A., Kupc, A., Metzger, A., Riccobono, F., Rondo, L., Schobesberger, S., Tsagkogeorgas, G., Wimmer, D., Amorim, A., Bianchi, F., Breitenlechner, M., David, A., Dommen, J., Downard, A., Ehn, M., Flagan, R. C., Haider, S., Hansel, A., Hauser, D., Jud, W., Junninen, H., Kreissl, F., Kvashin, A., Laaksonen, A., Lehtipalo, K., Lima, J., Lovejoy, E. R., Makhmutov, V., Mathot, S., Mikkilä, J., Minginette, P., Mogo, S., Nieminen, T., Onnela, A., Pereira, P., Petäjä, T., Schnitzhofer, R., Seinfeld, J. H., Sipilä, M., Stozhkov, Y., Stratmann, F., Tomé, A., Vanhanen, J., Viisanen, Y., Vrtala, A., Wagner, P. E., Walther, H., Weingartner, E., Wex, H., Winkler, P. M., Carslaw, K. S., Worsnop, D. R., Baltensperger, U., and Kulmala, M.: Role of sulphuric acid, ammonia and galactic cosmic rays in atmospheric aerosol nucleation, Nature, 476, 429-433, https://doi.org/10.1038/nature10343, 2011.

Kirkby, J., Duplissy, J., Sengupta, K., Frege, C., Gordon, H., Williamson, C., Heinritzi, M., Simon, M., Yan, C., Almeida, J., Trostl, J., Nieminen, T., Ortega, I. K., Wagner, R., Adamov, A., Amorim, A., Bernhammer, A. K., Bianchi, F., Breitenlechner, M., Brilke, S., Chen, X. M., Craven, J., Dias, A., Ehrhart, S., Flagan, R. C., Franchin, A., Fuchs, C., Guida, R., Hakala, J., Hoyle, C. R., Jokinen, T., Junninen, H., Kangasluoma, J., Kim, J., Krapf, M., Kurten, A., Laaksonen, A., Lehtipalo, K., Makhmutov, V., Mathot, S., Molteni, U., Onnela, A., Perakyla, O., Piel, F., Petaja, T., Praplan, A. P., Pringle, K., Rap, A., Richards, N. A. D., Riipinen, I., Rissanen, M. P., Rondo, L., Sarnela, N., Schobesberger, S., Scott, C. E., Seinfeld, J. H., Sipila, M., Steiner, G., Stozhkov, Y., Stratmann, F., Tome, A., Virtanen, A., Vogel, A. L., Wagner, A. C., Wagner, P. E., Weingartner, E., Wimmer, D., Winkler, P. M., Ye, P. L., Zhang, X., Hansel, A., Dommen, J., Donahue, N. M., Worsnop, D. R., Baltensperger, U., Kulmala, M., Carslaw, K. S., and Curtius, J.: Ion-induced nucleation of pure biogenic particles, Nature, 533, 521-526, https://doi.org/10.1038/nature17953, 2016.

Koenig, T. K., Baidar, S., Campuzano-Jost, P., Cuevas, C. A., Dix, B., Fernandez, R. P., Guo, H., Hall, S. R., Kinnison, D., Nault, B. A., Ullmann, K., Jimenez, J. L., Saiz-Lopez, A., and Volkamer, R.: Quantitative detection of iodine in the stratosphere, P. Natl. Acad. Sci. USA, 117, 1860-1866, https://doi.org/10.1073/pnas.1916828117, 2020. 
Kremser, S., Thomason, L. W., von Hobe, M., Hermann, M., Deshler, T., Timmreck, C., Toohey, M., Stenke, A., Schwarz, J. P., Weigel, R., Fueglistaler, S., Prata, F. J., Vernier, J. P., Schlager, H., Barnes, J. E., Antuna-Marrero, J. C., Fairlie, D., Palm, M., Mahieu, E., Notholt, J., Rex, M., Bingen, C., Vanhellemont, F., Bourassa, A., Plane, J. M. C., Klocke, D., Carn, S. A., Clarisse, L., Trickl, T., Neely, R., James, A. D., Rieger, L., Wilson, J. C., and Meland, B.: Stratospheric aerosol-Observations, processes, and impact on climate, Rev. Geophys., 54, 278-335, https://doi.org/10.1002/2015rg000511, 2016.

Kuang, C., McMurry, P. H., McCormick, A. V., and Eisele, F. L.: Dependence of nucleation rates on sulfuric acid vapor concentration in diverse atmospheric locations, J. Geophys. Res.-Atmos., 113, D10209, https://doi.org/10.1029/2007jd009253, 2008.

Kulmala, M., Kontkanen, J., Junninen, H., Lehtipalo, K., Manninen, H. E., Nieminen, T., Petaja, T., Sipila, M., Schobesberger, S., Rantala, P., Franchin, A., Jokinen, T., Jarvinen, E., Aijala, M., Kangasluoma, J., Hakala, J., Aalto, P. P., Paasonen, P., Mikkila, J., Vanhanen, J., Aalto, J., Hakola, H., Makkonen, U., Ruuskanen, T., Mauldin, R. L., Duplissy, J., Vehkamaki, H., Back, J., Kortelainen, A., Riipinen, I., Kurten, T., Johnston, M. V., Smith, J. N., Ehn, M., Mentel, T. F., Lehtinen, K. E. J., Laaksonen, A., Kerminen, V. M., and Worsnop, D. R.: Direct Observations of Atmospheric Aerosol Nucleation, Science, 339, $943-$ 946, https://doi.org/10.1126/science.1227385, 2013.

Kunkel, D., Hoor, P., Kaluza, T., Ungermann, J., Kluschat, B., Giez, A., Lachnitt, H.-C., Kaufmann, M., and Riese, M.: Evidence of small-scale quasi-isentropic mixing in ridges of extratropical baroclinic waves, Atmos. Chem. Phys., 19, 12607-12630, https://doi.org/10.5194/acp-19-12607-2019, 2019.

Kupc, A., Williamson, C., Wagner, N. L., Richardson, M., and Brock, C. A.: Modification, calibration, and performance of the Ultra-High Sensitivity Aerosol Spectrometer for particle size distribution and volatility measurements during the Atmospheric Tomography Mission (ATom) airborne campaign, Atmos. Meas. Tech., 11, 369-383, https://doi.org/10.5194/amt-11-369-2018, 2018.

Kupc, A., Williamson, C. J., Hodshire, A. L., Kazil, J., Ray, E., Bui, T. P., Dollner, M., Froyd, K. D., McKain, K., Rollins, A., Schill, G. P., Thames, A., Weinzierl, B. B., Pierce, J. R., and Brock, C. A.: The potential role of organics in new particle formation and initial growth in the remote tropical upper troposphere, Atmos. Chem. Phys., 20, 15037-15060, https://doi.org/10.5194/acp-2015037-2020, 2020.

Kürten, A., Bianchi, F., Almeida, J., Kupiainen-Määttä, O., Dunne, E. M., Duplissy, J., Williamson, C., Barmet, P., Breitenlechner, M., Dommen, J., Donahue, N. M., Flagan, R. C., Franchin, A., Gordon, H., Hakala, J., Hansel, A., Heinritzi, M., Ickes, L., Jokinen, T., Kangasluoma, J., Kim, J., Kirkby, J., Kupc, A., Lehtipalo, K., Leiminger, M., Makhmutov, V., Onnela, A., Ortega, I. K., Petäjä, T., Praplan, A. P., Riccobono, F., Rissanen, M. P., Rondo, L., Schnitzhofer, R., Schobesberger, S., Smith, J. N., Steiner, G., Stozhkov, Y., Tomé, A., Tröstl, J., Tsagkogeorgas, G., Wagner, P. E., Wimmer, D., Ye, P., Baltensperger, U., Carslaw, K., Kulmala, M., and Curtius, J.: Experimental particle formation rates spanning tropospheric sulfuric acid and ammonia abundances, ion production rates, and temperatures, J. Geophys. Res.-Atmos., 121, 12377-12400, https://doi.org/10.1002/2015jd023908, 2016.
Lamarque, J.-F., Bond, T. C., Eyring, V., Granier, C., Heil, A., Klimont, Z., Lee, D., Liousse, C., Mieville, A., Owen, B., Schultz, M. G., Shindell, D., Smith, S. J., Stehfest, E., Van Aardenne, J., Cooper, O. R., Kainuma, M., Mahowald, N., McConnell, J. R., Naik, V., Riahi, K., and van Vuuren, D. P.: Historical (1850-2000) gridded anthropogenic and biomass burning emissions of reactive gases and aerosols: methodology and application, Atmos. Chem. Phys., 10, 7017-7039, https://doi.org/10.5194/acp-10-7017-2010, 2010.

Lee, D. S., Pitari, G., Grewe, V., Gierens, K., Penner, J. E., Petzold, A., Prather, M. J., Schumann, U., Bais, A., Berntsen, T., Iachetti, D., Lim, L. L., and Sausen, R.: Transport impacts on atmosphere and climate: Aviation, Atmos. Environ., 44, 46784734, https://doi.org/10.1016/j.atmosenv.2009.06.005, 2010.

Lee, D. S., Fahey, D. W., Skowron, A., Allen, M. R., Burkhardt, U., Chen, Q., Doherty, S. J., Freeman, S., Forster, P. M., Fuglestvedt, J., Gettelman, A., De León, R. R., Lim, L. L., Lund, M. T., Millar, R. J., Owen, B., Penner, J. E., Pitari, G., Prather, M. J., Sausen, R., and Wilcox, L. J.: The contribution of global aviation to anthropogenic climate forcing for 2000 to 2018, Atmos. Environ., 244, 117834, https://doi.org/10.1016/j.atmosenv.2020.117834, 2020.

Lelieveld, J., Bourtsoukidis, E., Brühl, C., Fischer, H., Fuchs, H., Harder, H., Hofzumahaus, A., Holland, F., Marno, D., Neumaier, M., Pozzer, A., Schlager, H., Williams, J., Zahn, A., and Ziereis, H.: The South Asian monsoon - pollution pump and purifier, Science, 361, 270-273, https://doi.org/10.1126/science.aar2501, 2018.

Lovejoy, E. R. and Curtius, J.: Cluster Ion Thermal Decomposition (II): Master Equation Modeling in the LowPressure Limit and Fall-Off Regions. Bond Energies for $\mathrm{HSO}_{4}^{-}\left(\mathrm{H}_{2} \mathrm{SO}_{4}\right)_{x}\left(\mathrm{HNO}_{3}\right)_{y}$, J. Phys. Chem. A, 105, 10874 10883, https://doi.org/10.1021/jp012496s, 2001.

Lovejoy, E. R., Hanson, D. R., and Huey, L. G.: Kinetics and Products of the Gas-Phase Reaction of $\mathrm{SO}_{3}$ with Water, J. Phys. Chem.-US, 100, 19911-19916, https://doi.org/10.1021/jp962414d, 1996.

Lovejoy, E. R., Curtius, J., and Froyd, K. D.: Atmospheric ioninduced nucleation of sulfuric acid and water, J. Geophys. Res.Atmos., 109, D08204, https://doi.org/10.1029/2003jd004460, 2004.

Määttänen, A., Merikanto, J., Henschel, H., Duplissy, J., Makkonen, R., Ortega, I. K., and Vehkamäki, H.: New Parameterizations for Neutral and Ion-Induced Sulfuric Acid-Water Particle Formation in Nucleation and Kinetic Regimes, J. Geophys. Res.-Atmos., 123, 1269-1296, https://doi.org/10.1002/2017JD027429, 2018.

MacMartin, D. G. and Kravitz, B.: Mission-driven research for stratospheric aerosol geoengineering, P. Natl. Acad. Sci. USA, 116, 1089-1094, https://doi.org/10.1073/pnas.1811022116, 2019.

Manney, G. L., Hegglin, M. I., Daffer, W. H., Schwartz, M. J., Santee, M. L., and Pawson, S.: Climatology of Upper TroposphericLower Stratospheric (UTLS) Jets and Tropopauses in MERRA, J. Climate, 27, 3248-3271, https://doi.org/10.1175/jcli-d-1300243.1, 2014.

McCoy, I. L., McCoy, D. T., Wood, R., Regayre, L., Watson-Parris, D., Grosvenor, D. P., Mulcahy, J. P., Hu, Y., Bender, F. A.M., Field, P. R., Carslaw, K. S., and Gordon, H.: The hemispheric contrast in cloud microphysical properties constrains 
aerosol forcing, P. Natl. Acad. Sci. USA, 117, 18998-19006, https://doi.org/10.1073/pnas.1922502117, 2020.

McFiggans, G., Bale, C. S. E., Ball, S. M., Beames, J. M., Bloss, W. J., Carpenter, L. J., Dorsey, J., Dunk, R., Flynn, M. J., Furneaux, K. L., Gallagher, M. W., Heard, D. E., Hollingsworth, A. M., Hornsby, K., Ingham, T., Jones, C. E., Jones, R. L., Kramer, L. J., Langridge, J. M., Leblanc, C., LeCrane, J.-P., Lee, J. D., Leigh, R. J., Longley, I., Mahajan, A. S., Monks, P. S., Oetjen, H., Orr-Ewing, A. J., Plane, J. M. C., Potin, P., Shillings, A. J. L., Thomas, F., von Glasow, R., Wada, R., Whalley, L. K., and Whitehead, J. D.: Iodine-mediated coastal particle formation: an overview of the Reactive Halogens in the Marine Boundary Layer (RHaMBLe) Roscoff coastal study, Atmos. Chem. Phys., 10, 2975-2999, https://doi.org/10.5194/acp10-2975-2010, 2010.

Mills, M. J., Schmidt, A., Easter, R., Solomon, S., Kinnison, D. E., Ghan, S. J., Neely III, R. R., Marsh, D. R., Conley, A., Bardeen, C. G., and Gettelman, A.: Global volcanic aerosol properties derived from emissions, 1990-2014, using CESM1(WACCM), J. Geophys. Res.-Atmos., 121, 2332-2348, https://doi.org/10.1002/2015jd024290, 2016.

Murphy, D. M., Hudson, P. K., Thomson, D. S., Sheridan, P. J., and Wilson, J. C.: Observations of MercuryContaining Aerosols, Environ. Sci. Technol., 40, 3163-3167, https://doi.org/10.1021/es052385x, 2006.

Murphy, D. M., Froyd, K. D., Schwarz, J. P., and Wilson, J. C.: Observations of the chemical composition of stratospheric aerosol particles, Q. J. Roy. Meteor. Soc., 140, 1269-1278, https://doi.org/10.1002/qj.2213, 2014.

Murphy, D. M., Froyd, K. D., Bourgeois, I., Brock, C. A., Kupc, A., Peischl, J., Schill, G. P., Thompson, C. R., Williamson, C. J., and Yu, P.: Radiative and chemical implications of the size and composition of aerosol particles in the existing or modified global stratosphere, Atmos. Chem. Phys. Discuss. [preprint], https://doi.org/10.5194/acp-2020-909, in review, 2020.

National Academies of Sciences, Engineering, and Medicine: Reflecting Sunlight: Recommendations for Solar Geoengineering Research and Research Governance, Washington, DC: The National Academies Press, https://doi.org/10.17226/25762, 2021.

National Research Council: Climate intervention: reflecting sunlight to cool earth. Washington, DC: The National Academies Press, https://doi.org/10.17226/18988, 2015.

NCEP: National Centers for Environmental Prediction/National Weather Service/NOAA/U.S. Department of Commerce: NCEP GFS 0.25 Degree Global Forecast Grids Historical Archive, Research Data Archive, National Center for Atmospheric Research, Computational and Information Systems Laboratory, Boulder, Colorado, USA, available at: https://doi.org/10.5065/D65D8PWK, 2015.

Neely III, R. R., Toon, O. B., Solomon, S., Vernier, J.-P., Alvarez, C., English, J. M., Rosenlof, K. H., Mills, M. J., Bardeen, C. G., Daniel, J. S., and Thayer, J. P.: Recent anthropogenic increases in $\mathrm{SO}_{2}$ from Asia have minimal impact on stratospheric aerosol, Geophys. Res. Lett., 40, 999-1004, https://doi.org/10.1002/grl.50263, 2013.

O'Brien, K.: The theory of cosmic-ray and high-energy solarparticle transport in the atmosphere, Elsevier, 7, 29-44, https://doi.org/10.1016/S1569-4860(04)07004-4, 2005.
O’Dowd, C., McFiggans, G., Creasey, D. J., Pirjola, L., Hoell, C., Smith, M. H., Allan, B. J., Plane, J. M. C., Heard, D. E., Lee, J. D., Pilling, M. J., and Kulmala, M.: On the photochemical production of new particles in the coastal boundary layer, Geophys. Res. Lett., 26, 1707-1710, https://doi.org/10.1029/1999GL900335, 1999.

O’Dowd, C. D., Hämeri, K., Mäkelä, J. M., Pirjola, L., Kulmala, M., Jennings, S. G., Berresheim, H., Hansson, H.-C., de Leeuw, G., Kunz, G. J., Allen, A. G., Hewitt, C. N., Jackson, A., Viisanen, Y., and Hoffmann, T.: A dedicated study of New Particle Formation and Fate in the Coastal Environment (PARFORCE): Overview of objectives and achievements, J. Geophys. Res.-Atmos., 107, 8108, https://doi.org/10.1029/2001JD000555, 2002.

Paasonen, P., Asmi, A., Petäjä, T., Kajos, M. K., Äijälä, M., Junninen, H., Holst, T., Abbatt, J. P. D., Arneth, A., Birmili, W., van der Gon, H. D., Hamed, A., Hoffer, A., Laakso, L., Laaksonen, A., Richard Leaitch, W., Plass-Dülmer, C., Pryor, S. C., Räisänen, P., Swietlicki, E., Wiedensohler, A., Worsnop, D. R., Kerminen, V.-M., and Kulmala, M.: Warming-induced increase in aerosol number concentration likely to moderate climate change, Nat. Geosci., 6, 438-442, https://doi.org/10.1038/ngeo1800, 2013.

Parrish, D. D., Hahn, C. J., Williams, E. J., Norton, R. B., Fehsenfeld, F. C., Singh, H. B., Shetter, J. D., Gandrud, B. W., and Ridley, B. A.: Indications of photochemical histories of Pacific air masses from measurements of atmospheric trace species at Point Arena, California, J. Geophys. Res.-Atmos., 97, 15883-15901, https://doi.org/10.1029/92JD01242, 1992.

Randel, W. J., Park, M., Emmons, L., Kinnison, D., Bernath, P., Walker, K. A., Boone, C., and Pumphrey, H.: Asian Monsoon Transport of Pollution to the Stratosphere, Science, 328, 611613, https://doi.org/10.1126/science.1182274, 2010.

Riccobono, F., Schobesberger, S., Scott, C. E., Dommen, J., Ortega, I. K., Rondo, L., Almeida, J., Amorim, A., Bianchi, F., Breitenlechner, M., David, A., Downard, A., Dunne, E. M., Duplissy, J., Ehrhart, S., Flagan, R. C., Franchin, A., Hansel, A., Junninen, H., Kajos, M., Keskinen, H., Kupc, A., Kurten, A., Kvashin, A. N., Laaksonen, A., Lehtipalo, K., Makhmutov, V., Mathot, S., Nieminen, T., Onnela, A., Petaja, T., Praplan, A. P., Santos, F. D., Schallhart, S., Seinfeld, J. H., Sipila, M., Spracklen, D. V., Stozhkov, Y., Stratmann, F., Tome, A., Tsagkogeorgas, G., Vaattovaara, P., Viisanen, Y., Vrtala, A., Wagner, P. E., Weingartner, E., Wex, H., Wimmer, D., Carslaw, K. S., Curtius, J., Donahue, N. M., Kirkby, J., Kulmala, M., Worsnop, D. R., and Baltensperger, U.: Oxidation Products of Biogenic Emissions Contribute to Nucleation of Atmospheric Particles, Science, 344, 717-721, https://doi.org/10.1126/science.1243527, 2014.

Rollins, A. W., Thornberry, T. D., Watts, L. A., Yu, P., Rosenlof, K. H., Mills, M., Baumann, E., Giorgetta, F. R., Bui, T. V., Höpfner, M., Walker, K. A., Boone, C., Bernath, P. F., Colarco, P. R., Newman, P. A., Fahey, D. W., and Gao, R. S.: The role of sulfur dioxide in stratospheric aerosol formation evaluated by using in situ measurements in the tropical lower stratosphere, Geophys. Res. Lett., 44, 4280-4286, https://doi.org/10.1002/2017gl072754, 2017.

Rollins, A. W., Thornberry, T. D., Atlas, E., Navarro, M., Schauffler, S., Moore, F., Elkins, J. W., Ray, E., Rosenlof, K., Aquila, V., and Gao, R.-S.: $\mathrm{SO}_{2}$ Observations and Sources in the Western Pa- 
cific Tropical Tropopause Region, J. Geophys. Res.-Atmos., 123, 13549-13559, https://doi.org/10.1029/2018JD029635, 2018.

Schröder, F., Brock, C. A., Baumann, R., Petzold, A., Busen, R., Schulte, P., and Fiebig, M.: In situ studies on volatile jet exhaust particle emissions: Impact of fuel sulfur content and environmental conditions on nuclei mode aerosols, J. Geophys. Res.-Atmos., 105, 19941-19954, https://doi.org/10.1029/2000jd900112, 2000.

Scott, S. G., Bui, T. P., Chan, K. R., and Bowen, S. W.: The Meteorological Measurement System on the NASA ER-2 Aircraft, J. Atmos. Ocean. Tech., 7, 525-540, https://doi.org/10.1175/15200426(1990)007<0525:Tmmsot>2.0.Co;2, 1990.

Seinfeld, J. H. and Pandis, S. N.: Atmospheric chemistry and physics from air pollution to climate change, edn. 2, Wiley, Hoboken, New Jersey, USA, 1203 pp., 2006.

Sheng, J.-X., Weisenstein, D. K., Luo, B.-P., Rozanov, E., Stenke, A., Anet, J., Bingemer, H., and Peter, T.: Global atmospheric sulfur budget under volcanically quiescent conditions: Aerosol-chemistry-climate model predictions and validation, J. Geophys. Res.-Atmos., 120, 256-276, https://doi.org/10.1002/2014JD021985, 2015.

Shepherd, J. G.: Geoengineering the climate: an overview and update, Philos. T. Roy. Soc. A, 370, 4166-4175, https://doi.org/10.1098/rsta.2012.0186, 2012.

Simon, M., Dada, L., Heinritzi, M., Scholz, W., Stolzenburg, D., Fischer, L., Wagner, A. C., Kürten, A., Rörup, B., He, X.-C., Almeida, J., Baalbaki, R., Baccarini, A., Bauer, P. S., Beck, L., Bergen, A., Bianchi, F., Bräkling, S., Brilke, S., Caudillo, L., Chen, D., Chu, B., Dias, A., Draper, D. C., Duplissy, J., El-Haddad, I., Finkenzeller, H., Frege, C., Gonzalez-Carracedo, L., Gordon, H., Granzin, M., Hakala, J., Hofbauer, V., Hoyle, C. R., Kim, C., Kong, W., Lamkaddam, H., Lee, C. P., Lehtipalo, K., Leiminger, M., Mai, H., Manninen, H. E., Marie, G., Marten, R., Mentler, B., Molteni, U., Nichman, L., Nie, W., Ojdanic, A., Onnela, A., Partoll, E., Petäjä, T., Pfeifer, J., Philippov, M., Quéléver, L. L. J., Ranjithkumar, A., Rissanen, M. P., Schallhart, S., Schobesberger, S., Schuchmann, S., Shen, J., Sipilä, M., Steiner, G., Stozhkov, Y., Tauber, C., Tham, Y. J., Tomé, A. R., Vazquez-Pufleau, M., Vogel, A. L., Wagner, R., Wang, M., Wang, D. S., Wang, Y., Weber, S. K., Wu, Y., Xiao, M., Yan, C., Ye, P., Ye, Q., Zauner-Wieczorek, M., Zhou, X., Baltensperger, U., Dommen, J., Flagan, R. C., Hansel, A., Kulmala, M., Volkamer, R., Winkler, P. M., Worsnop, D. R., Donahue, N. M., Kirkby, J., and Curtius, J.: Molecular understanding of newparticle formation from $\alpha$-pinene between -50 and $+25^{\circ} \mathrm{C}$, Atmos. Chem. Phys., 20, 9183-9207, https://doi.org/10.5194/acp20-9183-2020, 2020.

Sipila, M., Sarnela, N., Jokinen, T., Henschel, H., Junninen, H., Kontkanen, J., Richters, S., Kangasluoma, J., Franchin, A., Perakyla, O., Rissanen, M. P., Ehn, M., Vehkamaki, H., Kurten, T., Berndt, T., Petaja, T., Worsnop, D., Ceburnis, D., Kerminen, V. M., Kulmala, M., and O'Dowd, C.: Molecular-scale evidence of aerosol particle formation via sequential addition of $\mathrm{HIO}_{3}, \mathrm{Na}-$ ture, 537, 532-534, https://doi.org/10.1038/nature19314, 2016.

Smith, J. N., Barsanti, K. C., Friedli, H. R., Ehn, M., Kulmala, M., Collins, D. R., Scheckman, J. H., Williams, B. J., and McMurry, P. H.: Observations of aminium salts in atmospheric nanoparticles and possible climatic implications, P. Natl. Acad. Sci. USA, 107, 6634-6639, https://doi.org/10.1073/pnas.0912127107, 2010.

Solomon, S., Daniel, J. S., Neely, R. R., Vernier, J.-P., Dutton, E. G., and Thomason, L. W.: The Persistently Variable "Background" Stratospheric Aerosol Layer and Global Climate Change, Science, 333, 866-870, https://doi.org/10.1126/science.1206027, 2011.

Spanu, A., Dollner, M., Gasteiger, J., Bui, T. P., and Weinzierl, B.: Flow-induced errors in airborne in situ measurements of aerosols and clouds, Atmos. Meas. Tech., 13, 1963-1987, https://doi.org/10.5194/amt-13-1963-2020, 2020.

Stolzenburg, D., Fischer, L., Vogel, A. L., Heinritzi, M., Schervish, M., Simon, M., Wagner, A. C., Dada, L., Ahonen, L. R., Amorim, A., Baccarini, A., Bauer, P. S., Baumgartner, B., Bergen, A., Bianchi, F., Breitenlechner, M., Brilke, S., Buenrostro Mazon, S., Chen, D., Dias, A., Draper, D. C., Duplissy, J., El Haddad, I., Finkenzeller, H., Frege, C., Fuchs, C., Garmash, O., Gordon, H., He, X., Helm, J., Hofbauer, V., Hoyle, C. R., Kim, C., Kirkby, J., Kontkanen, J., Kürten, A., Lampilahti, J., Lawler, M., Lehtipalo, K., Leiminger, M., Mai, H., Mathot, S., Mentler, B., Molteni, U., Nie, W., Nieminen, T., Nowak, J. B., Ojdanic, A., Onnela, A., Passananti, M., Petäjä, T., Quéléver, L. L. J., Rissanen, M. P., Sarnela, N., Schallhart, S., Tauber, C., Tomé, A., Wagner, R., Wang, M., Weitz, L., Wimmer, D., Xiao, M., Yan, C., Ye, P., Zha, Q., Baltensperger, U., Curtius, J., Dommen, J., Flagan, R. C., Kulmala, M., Smith, J. N., Worsnop, D. R., Hansel, A., Donahue, N. M., and Winkler, P. M.: Rapid growth of organic aerosol nanoparticles over a wide tropospheric temperature range, P. Natl. Acad. Sci. USA, 115, 9122-9127, https://doi.org/10.1073/pnas.1807604115, 2018.

Trostl, J., Chuang, W. K., Gordon, H., Heinritzi, M., Yan, C., Molteni, U., Ahlm, L., Frege, C., Bianchi, F., Wagner, R., Simon, M., Lehtipalo, K., Williamson, C., Craven, J. S., Duplissy, J., Adamov, A., Almeida, J., Bernhammer, A. K., Breitenlechner, M., Brilke, S., Dias, A., Ehrhart, S., Flagan, R. C., Franchin, A., Fuchs, C., Guida, R., Gysel, M., Hansel, A., Hoyle, C. R., Jokinen, T., Junninen, H., Kangasluoma, J., Keskinen, H., Kim, J., Krapf, M., Kurten, A., Laaksonen, A., Lawler, M., Leiminger, M., Mathot, S., Mohler, O., Nieminen, T., Onnela, A., Petaja, T., Piel, F. M., Miettinen, P., Rissanen, M. P., Rondo, L., Sarnela, N., Schobesberger, S., Sengupta, K., Sipila, M., Smith, J. N., Steiner, G., Tome, A., Virtanen, A., Wagner, A. C., Weingartner, E., Wimmer, D., Winkler, P. M., Ye, P. L., Carslaw, K. S., Curtius, J., Dommen, J., Kirkby, J., Kulmala, M., Riipinen, I., Worsnop, D. R., Donahue, N. M., and Baltensperger, U.: The role of low-volatility organic compounds in initial particle growth in the atmosphere, Nature, 533, 527-531, https://doi.org/10.1038/nature18271, 2016.

Tsigaridis, K., Daskalakis, N., Kanakidou, M., Adams, P. J., Artaxo, P., Bahadur, R., Balkanski, Y., Bauer, S. E., Bellouin, N., Benedetti, A., Bergman, T., Berntsen, T. K., Beukes, J. P., Bian, H., Carslaw, K. S., Chin, M., Curci, G., Diehl, T., Easter, R. C., Ghan, S. J., Gong, S. L., Hodzic, A., Hoyle, C. R., Iversen, T., Jathar, S., Jimenez, J. L., Kaiser, J. W., Kirkevåg, A., Koch, D., Kokkola, H., Lee, Y. H., Lin, G., Liu, X., Luo, G., Ma, X., Mann, G. W., Mihalopoulos, N., Morcrette, J.-J., Müller, J.-F., Myhre, G., Myriokefalitakis, S., Ng, N. L., O’Donnell, D., Penner, J. E., Pozzoli, L., Pringle, K. J., Russell, L. M., Schulz, M., Sciare, J., Seland, Ø., Shindell, D. T., Sillman, S., Skeie, R. B., 
Spracklen, D., Stavrakou, T., Steenrod, S. D., Takemura, T., Tiitta, P., Tilmes, S., Tost, H., van Noije, T., van Zyl, P. G., von Salzen, K., Yu, F., Wang, Z., Wang, Z., Zaveri, R. A., Zhang, H., Zhang, K., Zhang, Q., and Zhang, X.: The AeroCom evaluation and intercomparison of organic aerosol in global models, Atmos. Chem. Phys., 14, 10845-10895, https://doi.org/10.5194/acp-1410845-2014, 2014.

Vellinga, M. and Wood, R. A.: Global Climatic Impacts of a Collapse of the Atlantic Thermohaline Circulation, Climatic Change, 54, 251-267, https://doi.org/10.1023/A:1016168827653, 2002.

Vernier, J.-P., Thomason, L. W., Pommereau, J.-P., Bourassa, A., Pelon, J., Garnier, A., Hauchecorne, A., Blanot, L., Trepte, C., Degenstein, D., and Vargas, F.: Major influence of tropical volcanic eruptions on the stratospheric aerosol layer during the last decade, Geophys. Res. Lett., 38, L12807, https://doi.org/10.1029/2011g1047563, 2011.

Volkamer, R., Baidar, S., Campos, T. L., Coburn, S., DiGangi, J. P., Dix, B., Eloranta, E. W., Koenig, T. K., Morley, B., Ortega, I., Pierce, B. R., Reeves, M., Sinreich, R., Wang, S., Zondlo, M. A., and Romashkin, P. A.: Aircraft measurements of BrO, IO, glyoxal, $\mathrm{NO}_{2}, \mathrm{H}_{2} \mathrm{O}, \mathrm{O}_{2}-\mathrm{O}_{2}$ and aerosol extinction profiles in the tropics: comparison with aircraft-/ship-based in situ and lidar measurements, Atmos. Meas. Tech., 8, 2121-2148, https://doi.org/10.5194/amt-8-2121-2015, 2015.

Williamson, C., Kupc, A., Wilson, J., Gesler, D. W., Reeves, J. M., Erdesz, F., McLaughlin, R., and Brock, C. A.: Fast time response measurements of particle size distributions in the $3-60 \mathrm{~nm}$ size range with the nucleation mode aerosol size spectrometer, Atmos. Meas. Tech., 11, 3491-3509, https://doi.org/10.5194/amt11-3491-2018, 2018.

Williamson, C. J., Kupc, A., Axisa, D., Bilsback, K. R., Bui, T., Campuzano-Jost, P., Dollner, M., Froyd, K. D., Hodshire, A. L., Jimenez, J. L., Kodros, J. K., Luo, G., Murphy, D. M., Nault, B. A., Ray, E. A., Weinzierl, B., Wilson, J. C., Yu, F. Q., Yu, P. F., Pierce, J. R., and Brock, C. A.: A large source of cloud condensation nuclei from new particle formation in the tropics, Nature, 574, 399-403, https://doi.org/10.1038/s41586-019-1638-9, 2019.

Wilson, J. C., Stolzenburg, M. R., Clark, W. E., Loewenstein, M., Ferry, G. V., Chan, K. R., and Kelly, K. K.: Stratospheric sulfate aerosol in and near the northern hemisphere polar vortex: The morphology of the sulfate layer, multimodal size distributions, and the effect of denitrification, J. Geophys. Res.-Atmos., 97, 7997-8013, https://doi.org/10.1029/92JD00065, 1992.

Wilson, J. C., Lee, S.-H., Reeves, J. M., Brock, C. A., Jonsson, H. H., Lafleur, B. G., Loewenstein, M., Podolske, J., Atlas, E., Boering, K., Toon, G., Fahey, D., Bui, T. P., Diskin, G., and Moore, F.: Steady-state aerosol distributions in the extra-tropical, lower stratosphere and the processes that maintain them, Atmos. Chem. Phys., 8, 6617-6626, https://doi.org/10.5194/acp-8-6617-2008, 2008 .
Williamson, C. J., Kupc, A., Rollins, A. W., Kazil, J., Froyd, K. D., Ray, E. A., Murphy, D. M., Schill, G. P., Peischl, J., Thompson, C. R., Bourgeois, I., Ryerson, T. B., Diskin, G. S., DiGangi, J. P., Blake, D. R., Bui, T. P., Dollner, M., Weinzierl, B. B., and Brock, C. A.: Ultrafine aerosol and sulfate in the lowermost stratosphere (Version 1), ORNL Distributed Active Archive Center, available at: https://doi.org/10.3334/ORNLDAAC/1868, last access: 12 April 2021.

Wofsy, S. C., Afshar, S., Allen, H. M., Apel, E., Asher, E. C., Barletta, B., Bent, J., Bian, H., Biggs, B. C., Blake, D. R., Blake, N., Bourgeois, I., Brock, C. A., Brune, W. H., Budney, J. W., Bui, T. P., Butler, A., Campuzano-Jost, P., Chang, C. S., Chin, M., Commane, R., Correa, G., Crounse, J. D., Cullis, P. D., Daube, B. C., Day, D. A., Dean-Day, J. M., Dibb, J. E., Digangi, J. P., Diskin, G. S., Dollner, M., Elkins, J. W., Erdesz, F., Fiore, A. M., Flynn, C. M., Froyd, K., Gesler, D. W., Hall, S. R., Hanisco, T. F., Hannun, R. A., Hills, A. J., Hintsa, E. J., Hoffman, A., Hornbrook, R. S., Huey, L. G., Hughes, S., Jimenez, J. L., Johnson, B. J., Katich, J. M., Keeling, R., Kim, M. J., Kupc, A., Lait, L. R., Lamarque, J. F., Liu, J., McKain, K., McLaughlin, R. J., Meinardi, S., Miller, D. O., Montzka, S. A., Moore, F. L., Morgan, E. J., Murphy, D. M., Murray, L. T., Nault, B. A., Neuman, J. A., Newman, P. A., Nicely, J. M., Pan, X., Paplawsky, W., Peischl, J., Prather, M. J., Price, D. J., Ray, E., Reeves, J. M., Richardson, M., Rollins, A. W., Rosenlof, K. H., Ryerson, T. B., Scheuer, E., Schill, G. P., Schröder, J. C., Schwarz, J. P., St. Clair, J. M., Steenrod, S. D., Stephens, B. B., Strode, S. A., Sweeney, C., Tanner, D., Teng, A. P., Thames, A. B., Thompson, C. R., Ullmann, K., Veres, P. R., Vizenor, N., Wagner, N. L., Watt, A., Weber, R., Weinzierl, B., Wennberg, P., Williamson, C. J., Wilson, J. C., Wolfe, G. M., Woods, C. T., and Zeng, L. H.: ATom: Merged Atmospheric Chemistry, Trace Gases, and Aerosols, ORNL Distributed Active Archive Center [data set], available at: https://doi.org/10.3334/ORNLDAAC/1581 (last access: December 2020), 2018.

Yu, P., Murphy, D. M., Portmann, R. W., Toon, O. B., Froyd, K. D., Rollins, A. W., Gao, R.-S., and Rosenlof, K. H.: Radiative forcing from anthropogenic sulfur and organic emissions reaching the stratosphere, Geophys. Res. Lett., 43, 9361-9367, https://doi.org/10.1002/2016GL070153, 2016.

Yu, P., Rosenlof, K. H., Liu, S., Telg, H., Thornberry, T. D., Rollins, A. W., Portmann, R. W., Bai, Z., Ray, E. A., Duan, Y., Pan, L. L., Toon, O. B., Bian, J., and Gao, R.-S.: Efficient transport of tropospheric aerosol into the stratosphere via the Asian summer monsoon anticyclone, P. Natl. Acad. Sci. USA, 114, 6972-6977, https://doi.org/10.1073/pnas.1701170114, 2017.

Yu, P., Toon, O. B., Bardeen, C. G., Zhu, Y., Rosenlof, K. H., Portmann, R. W., Thornberry, T. D., Gao, R.-S., Davis, S. M., Wolf, E. T., de Gouw, J., Peterson, D. A., Fromm, M. D., and Robock, A.: Black carbon lofts wildfire smoke high into the stratosphere to form a persistent plume, Science, 365, 587-590, https://doi.org/10.1126/science.aax1748, 2019. 